\title{
A multi-proxy perspective on millennium-long climate variability in the Southern Pyrenees
}

\author{
M. Morellónn ${ }^{1,2,3}$, A. Pérez-Sanz ${ }^{3}$, J. P. Corella ${ }^{2,3}$, U. Büntgen ${ }^{4}$, J. Catalán ${ }^{5}$, P. González-Sampériz ${ }^{3}$, \\ J. J. González-Trueba ${ }^{6}$, J. A. López-Sáez ${ }^{7}$, A. Moreno ${ }^{2,3}$, S. Pla-Rabes ${ }^{5}$, M. Á. Saz-Sánchez ${ }^{8}$, P. Scussolini ${ }^{9,12}$, \\ E. Serrano ${ }^{10}$, F. Steinhilber ${ }^{1}$, V. Stefanova ${ }^{11}$, T. Vegas-Vilarrúbia ${ }^{12}$, and B. Valero-Garcés ${ }^{2,3}$ \\ ${ }^{1}$ Eawag, Swiss Federal Institute of Aquatic Science and Technology, Department of Surface Waters, berlandstrasse 133, \\ 8600 Dübendorf, Switzerland \\ ${ }^{2}$ Laboratorio Internacional de Cambio Global (LINCGlobal), PUC-CSIC, Departamento de Ecología, \\ Facultad de Ciencias Biológicas, PUC, Alameda 340, PC 6513677 Santiago, Chile \\ ${ }^{3}$ Departamento de Procesos Geoambientales y Cambio Global, Instituto Pirenaico de Ecología (IPE) - CSIC, \\ Campus de Aula Dei. Avda, Montañana 1005, 50059 Zaragoza, Spain \\ ${ }^{4}$ Swiss Federal Research Institute for Forest, Snow and Landscape (WSL) ETH domain Zürich, \\ 8903 Birmensdorf, Switzerland \\ ${ }^{5}$ Centre d'Estudis Avançats de Blanes (CEAB) - CSIC. C/ Accés a la Cala St. Francesc, 14, 17300 Blanes, Spain \\ ${ }^{6}$ Departamento de Geografía, Prehistoria y Arqueología, Calle Tomás y Valiente s/n. 01006 Vitoria-Gasteiz, Spain \\ ${ }^{7}$ Centro de Ciencias Humanas y Sociales, CCHS-CSIC, C/ Albasanz, 26-28, 28037 Madrid, Spain \\ ${ }^{8}$ Departamento de Geografía y Ordenación del Territorio, Facultad de Filosofía y Letras, Universidad de Zaragoza, \\ Calle Pedro Cerbuna 12, 50009 Zaragoza, Spain \\ ${ }^{9}$ Faculty of Earth and Life Sciences, Department of Marine Biogeology, Vrije Universiteit, De Boelelaan 1085, \\ 1081HV Amsterdam, The Netherlands \\ ${ }^{10}$ Subunidad de Geografía Física Departamento de Geografía, Facultad de Filosofía y Letras, Plaza del Campus s/n, \\ 47011 Valladolid, Spain \\ ${ }^{11}$ Limnological Research Center, University of Minnesota, 310 Pillsbury Drive SE, Minneapolis, MN 55455, USA \\ ${ }^{12}$ Departament of Ecology, Faculty of Biology, University of Barcelona, Av, Diagonal 645, 08028 Barcelona, Spain
}

Correspondence to: M. Morellón (mario.morellon-marteles@eawag.ch)

Received: 23 September 2011 - Published in Clim. Past Discuss.: 4 October 2011

Revised: 5 February 2012 - Accepted: 12 March 2012 - Published: 30 March 2012

\begin{abstract}
This paper reviews multi-proxy paleoclimatic reconstructions with robust age-control derived from lacustrine, dendrochronological and geomorphological records and characterizes the main environmental changes that occurred in the Southern Pyrenees during the last millennium. Warmer and relatively arid conditions prevailed during the Medieval Climate Anomaly (MCA, ca. 900-1300 AD), with a significant development of xerophytes and Mediterranean vegetation and limited deciduous tree formations (mesophytes). The Little Ice Age (LIA, 1300-1800 AD) was generally colder and moister, with an expansion of deciduous taxa and cold-adapted montane conifers. Two major phases occurred within this period: (i) a transition MCA-LIA, characterized by fluctuating, moist conditions and relatively cold temperatures (ca. 1300 and $1600 \mathrm{AD}$ ); and (ii) a second period, characterized by the coldest and most humid conditions, coinciding with maximum (recent) glacier advances
\end{abstract}

(ca. 1600-1800 AD). Glaciers retreated after the LIA when warmer and more arid conditions dominated, interrupted by a short-living cooling episode during the late 19th to early 20 th centuries. Some records suggest a response to solar activity with colder and slightly moister conditions during solar minima. Centennial-scale hydrological fluctuations are in phase with reconstructions of NAO variability, which appears to be one of the main climate mechanisms influencing rainfall variations in the region during the last millennium.

\section{Introduction}

Climate reconstructions for the last millennium are crucial for our understanding of past natural variability and for assessing the influence of external forcing factors such as solar activity and volcanic eruptions. The perspective of a current 
global warming scenario has provoked an increasing interest in studies of climate fluctuations prior to the industrial era (Jansen et al., 2007). Furthermore, long-term palaeoclimatic perspectives offer an excellent basis to improve predictive models (Solomon et al., 2007). Past climate conditions have been reconstructed using various proxies, such as tree rings (Büntgen et al., 2011), lake sediments (Last and Smol, 2001), historical documents (Brázdil et al., 2005, 2010), marine sediments (Abrantes et al., 2005), corals (Goodkin et al., 2008), speleothems (Proctor et al., 2002), and, ideally, a combination thereof (Jones et al., 2009).

In spite of an wide range of associated uncertainties (Frank et al., 2010), most climate reconstructions agree on the existence of two different stages with distinct climatic conditions during the last millennium: a period of relatively high temperatures at $\sim 900-1300 \mathrm{AD}$, known as the Medieval Climate Anomaly (MCA); and a phase with relatively cooler temperatures at $\sim 1300-1800 \mathrm{AD}$, the so-called Little Ice Age (LIA). Unfavourable climate conditions during the LIA had also a considerable impact in European societies (Fagan, 2000). They likely contributed to the decline of health and economic wealth of medieval societies triggered by the Black Death (Büntgen et al., 2011), for instance, and led to the abandonment of different areas such as Norse settlements in Greenland (Patterson et al., 2010; D'Andrea et al., 2011). Despite the precise chronology, the spatial extent and mechanisms behind these climatic phases still remain a subject of debate (Paasche and Bakke, 2010).

The impact of the LIA on Central European ecosystems and societies has been widely documented (Büntgen et al., 2011; Magny et al., 2011b; Denton and Broecker, 2008). However, environmental responses to the LIA in the Mediterranean region are not yet well understood (Touchan et al., 2011; Esper et al., 2007; Büntgen et al., 2008, 2010b; Luterbacher et al., 2005). Several studies have suggested that the hydrological impact of climate changes will dramatically affect snow-fed watersheds, such as the headwaters of many rivers located in the Pyrenees (Beniston, 2003; GarcíaRuiz et al., 2011). The Southern Pyrenees constitute the main source of water resources at present, supplying more than $45 \%$ of the annual runoff to the surrounding semi-arid Ebro Basin, a relatively densely populated area of NE Spain (López-Moreno and García-Ruiz, 2004). To understand future climate changes induced by global warming it is necessary to assess the impact of climate change on the hydrological cycle and through examination of climate variability and threshold values during the last millennia.

New information from different palaeoclimatic archives in the Pyrenees during the last millennium has become available during recent years: lacustrine records (Valero-Garcés and Moreno, 2011, and references therein), glacier extension (González Trueba et al., 2008) and dendroclimatic reconstructions (Büntgen et al., 2008). Together they provide a unique opportunity to assess the timing, amplitude, and internal structure of this period, and a re-evaluation of the environmental changes associated with the LIA phase in the Southern Pyrenees. This paper reviews the available near millennium-long palaeoclimatic evidence from the Pyrenees, including: (i) glacier advances and retreats reconstructed from moraine sediments, (ii) the climatic and landscape changes evidenced by multi-proxy-based lake and shallow-marine sediments reconstructions, and (iii) the rainfall and temperature fluctuations evaluated from tree-ring chronologies. Comparison of these paleoclimate sequences and correlation with regional records across the Mediterranean region and mountain areas of Europe allows a more precise evaluation of the spatial extent and chronology of the main climate and environmental changes that occurred during the last millennium, and permits the testing of possible climate mechanisms for this type of event.

\section{Regional setting}

The Pyrenees are limited by the Bay of Biscay in the west and Cape Creus to the east (Fig. 1a) and represent a $\sim 440 \mathrm{~km}$ long longitudinal belt from the Atlantic Ocean to the Mediterranean Sea. This geographical location between these two climatic zones; their southern latitude and EastWest orientation and its complex topography lead to a high climatic heterogeneity (López-Moreno et al., 2008). Altitudes reach more than $3000 \mathrm{~m}$ above sea level (a.s.l.) with a highly contrasting relief (Del Barrio et al., 1990). The highest massifs are located in the central areas of the range and the altitude decreases towards the west and the east, as well as towards the Aquitaine (France) and Ebro Depressions (Spain) (north and south, respectively) (Fig. 1b). Annual precipitation exceeds $600 \mathrm{~mm}$ and sometimes even reaches $2000 \mathrm{~mm}$ at the highest altitudes. Most of the annual precipitation occurs during the cold season in the Atlantic areas but during spring and autumn in the Mediterranean regions, with relatively dry summers. The annual averaged $0^{\circ} \mathrm{C}$ isotherm is located at $\sim 2700 \mathrm{~m}$ a.s.l. (Del Barrio et al., 1990).

This study is restricted to the Southern Pyrenees, which are characterized by a stronger Mediterranean influence and thus, warmer and drier conditions than the northern slopes (Cuadrat et al., 2008), which makes this area more sensitive to hydrological fluctuations. In the highest altitudes (above $1800 \mathrm{~m}$ a.s.l.) vegetation is mainly composed of subalpine and alpine pastures (Carex curvula and Festuca scoparia) with conifers (Pinus uncinata and Juniperus sp) as the only arboreal component. Small forested areas of Fagus sylvatica, Fraxinus excelsior, Corylus avellana, Betula pubescens, Acer campestre, Sorbus aucuparia and Sorbus aria and mixed forest with Pinus sylvestris, Fagus sylvatica and Abies alba can be also found (Peinado Lorca and Rivas-Martínez, 1987). Between 1500 and $1800 \mathrm{~m}$, Pinus sylvestris and Quercus faginea forests are dominant, while at around $1000 \mathrm{~m}$ Mediterranean influence increases and vegetation is composed of Quercus ilex-rotundifolia and Quercus pubescens, 


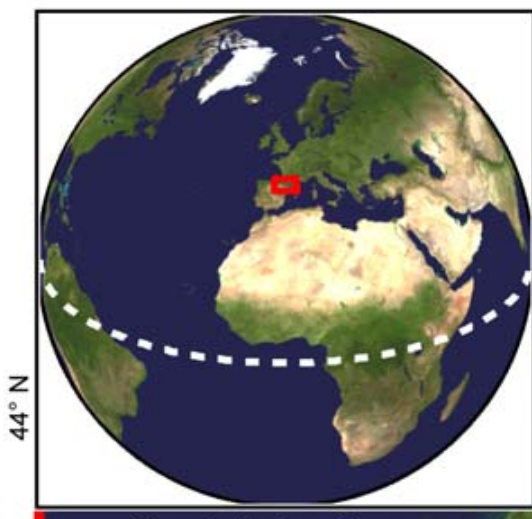
LEGEND
Main rivers
Reviewed Sites
Dendroclimatic
Lake
$\triangle$ Marine-Littoral
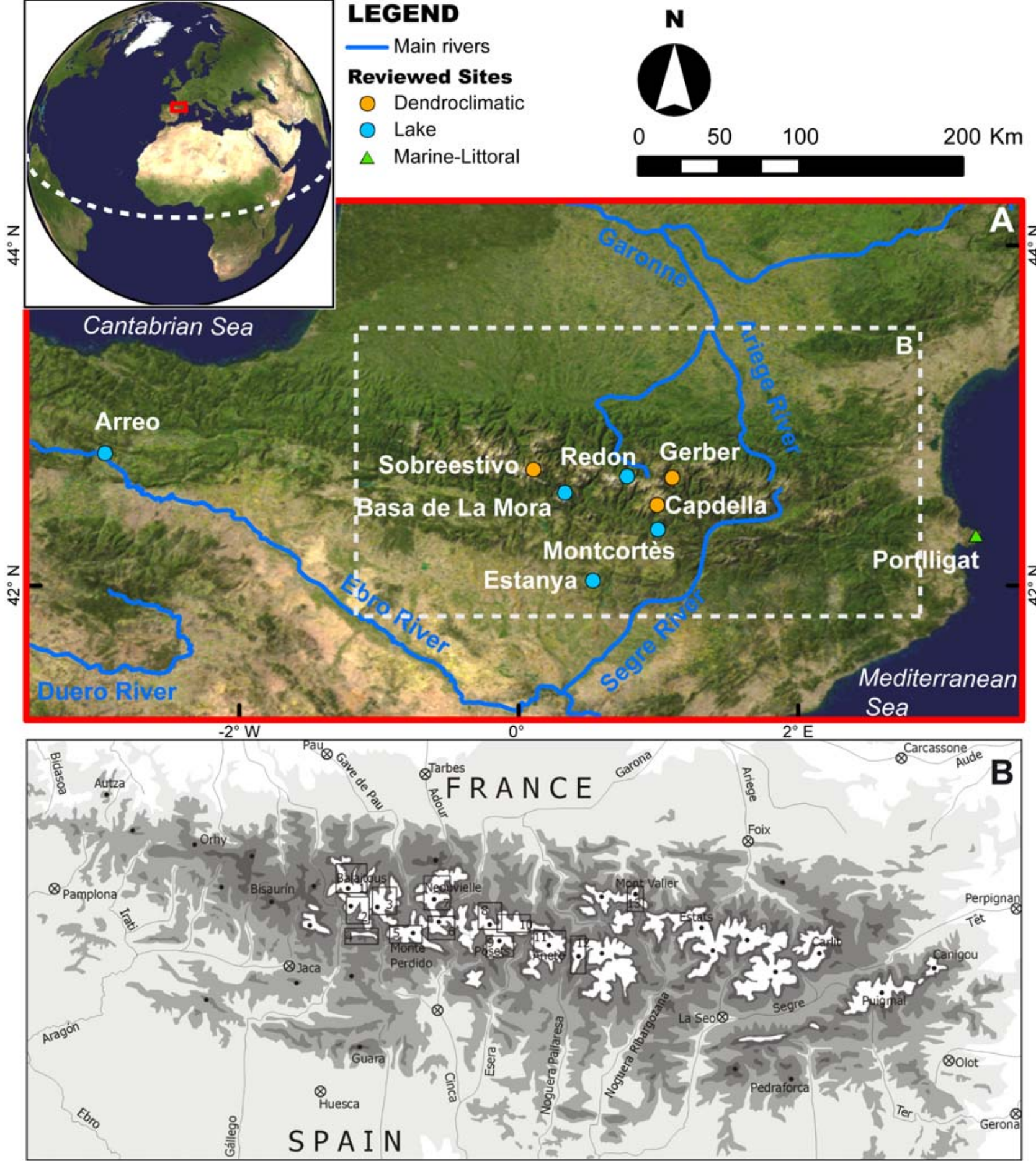

$\otimes$ villages
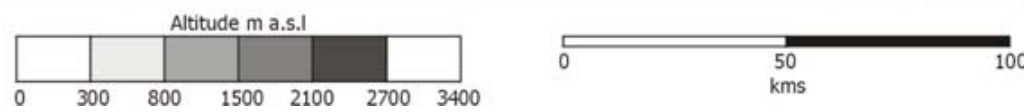

本

Fig. 1. (A) Location of the different records reviewed in this paper within the Pyrenees, including lacustrine, dendroclimatic and marinelittoral reconstructions (see legend). (B) Detailed map of the different massifs with the presence of glaciers during the LIA (modified from González-Trueba et al., 2008). 
depending on the annual precipitation. Foothills are mainly covered by Mediterranean pine (Pinus Sylvestris and Pinus Halepensis) and oak forests (Quercus ilex-rotundifolia, $Q$. faginea, $Q$. pubescens), with dense shrub land (Rhamnus, Pistacia, Arbutus, Prunus, Cornus, Buxus, Genisteae, Cistaceae, etc.). Corylus avellana and other phreatophytes such as Salix, Fraxinus, Populus or Ulmus are only located on riverine soils (Blanco-Castro et al., 1997).

There are two main types of lakes in the Southern Pyrenean domain (Fig. 1a): (i) karstic lakes, located at the Southern foothills of the Pyrenees, in the so-called External Ranges, between 600 and 1000 m a.s.l., in the transition between Atlantic and Mediterranean climate types and vegetation domains (García and Gómez, 2008) and subject to a considerable human influence during the last millennia (Arreo, Estanya, Montcortès); (ii) high-mountain, glacial lakes located in the Axial Pyrenees, above $1800 \mathrm{~m}$ a.s.l., characterized by colder and more humid conditions, near to the timberline (e.g. Basa de la Mora, Redon) where human impact is limited. Currently in the Pyrenees there are 21 active glaciers with a total extension of about 495 ha. On the Spanish side there are 29 ice bodies, of which only 10 can be considered as glaciers (260 ha) (González Trueba et al., 2008), and thus, appear the most relevant for this study. Nevertheless, LIA remains such as moraines and proglacial materials do exist in more than 100 deglaciated cirques in the Pyrenean high mountains. These deposits are located in the current glaciated and non-glaciated massifs (Fig. 1b) (Serrano and Martínez de Pisón, 1994; Grove and Gellatly, 1995; Chueca et al., 1998a, b). Although the Pyrenean glaciers experienced an expansion during the LIA, they are currently reduced in thickness and spatially limited to the highest summits, displaying bevelled shapes, burials, and even some disappearance of ice bodies. From 1880 to $1980 \mathrm{AD}$ at least 94 glaciers became extinct, while 17 glaciers have disappeared on the Spanish side since the 1980s.

\section{Paleoclimate archives}

For this study, we selected paleoclimate sequences from published studies that fulfill the following requirements: (i) reconstructions are based on natural archives, (ii) these records have independent chronologies based either on absolute dating (tree ring or lacustrine varve counting, calibrated radiometric dating) or documentary sources and (iii) climate variability is considered as the main forcing mechanism of environmental changes reconstructed at these sites. Paleoclimatic archives analyzed here comprise: (i) dendroclimatic reconstructions (Fig. 1a), (ii) lake and marine-littoral sequences (Fig. 1a), and (iii) geomorphologic evidence of glacier advances or retreats (Fig. 1b). Reconstructed environmental variables vary from climatic parameters (temperature, precipitation) to evidence of environmental changes directly related to these parameters (changes in vegetation cover, runoff and effective moisture fluctuations reconstructed by lake level changes and/or salinity fluctuations). We consider this transect of multi-proxy reconstructions of climatic and environmental changes to represent the best strategy to discern between climate and human forcings in landscape changes, as demonstrated in previous research carried out in this area (Moreno et al., 2008; Morellón et al., 2011; Rull et al., 2011).

\subsection{Lake and marine-littoral sequences}

Unravelling the complex interplay between climate changes and human impact in Pyrenean lakes and littoral marine sequences is complex and requires the use of multiple proxydata and robust chronologies based on either radiometric techniques $\left({ }^{137} \mathrm{Cs},{ }^{210} \mathrm{~Pb},{ }^{14} \mathrm{C}\right)$ or varve counting or a combination of these two methods. Furthermore, the correlation with historical events detected in most of the sequences provides further chronological support (e.g. onset and/or intensification of farming, introduction of particular cultivars, deforestation events (Rull et al., 2011)). Most of the lacustrine sequences used in this review have been analysed following a multidisciplinary strategy, comprising a variety of proxies: (i) sedimentology (sedimentary facies, microfacies and varve sub-layering), (ii) elemental and isotopic geochemistry, and (iii) biological indicators (pollen, diatoms, chironomids and chrysophytes). Other lake and peatbog records (i.e. Tramacastilla and Bubal (Montserrat-Martí, 1992), Bosc dels Estanyons (Miras et al., 2007), Riu dels Orris fen (Ejarque et al., 2010), Lake Burg (Bal et al., 2011) and Col d'Ech (Rius et al., 2012), among others), have not been considered for this paper because of the lack of a multi-proxy analysis or their exclusive focus on human activities.

\subsubsection{Lake Arreo}

Lake Arreo $\left(42^{\circ} 46^{\prime} \mathrm{N}, 2^{\circ} 59^{\prime} \mathrm{W}, 655 \mathrm{~m}\right.$ a.s.l. $)$ is a karstic lake located in the transition between the Westernmost Ebro Basin and the foothills of the Pyrenees (Fig. 1a). The chronology of the sequence is based on the combination of varve counting, ${ }^{137} \mathrm{Cs} /{ }^{210} \mathrm{~Pb}$, and ${ }^{14} \mathrm{C}$ dating and spans the last $2600 \mathrm{yr}$ (Corella, 2011). The main paleoindicators analysed include sedimentary facies and microfacies, elemental geochemistry, pollen and diatoms. The sensitivity of some of these proxies has been demonstrated by their successful correlation with instrumental climate data series and limnological monitoring data at shorter timescales (Corella et al., 2011a).

The onset of the LIA in the Arreo sequence (1300 AD) is characterized by a better development and preservation of biogenic varves, decreased content in aragonite and gypsum, and corresponding lower values of strontium $(\mathrm{Sr})$, and the increase in the centric diatom Cyclotella distinguenda and arboreal pollen. These proxies are indicative of the development of higher lake levels and associated meromixis, and a forest recovery likely caused by moister conditions (Table 1). Additionally, an increase in Typha indicates the flooding of the littoral platform previously emerged during the MCA. The decrease in deciduous Quercus since 1870 AD 
points towards more arid conditions since the end of the LIA. An arid phase was detected between 1730-1790 AD, characterized by a deposition of clay-rich facies (Fig. 2) and high Sr content in the sediment (Corella, 2011) (Table 1, Fig. 3). Nevertheless, the presence of biogenic varves, and the dominant presence of Cyclotella distingüenda and the low $\mathrm{Sr}$ values indicates relatively high lake levels during the mid19th-mid-20th century (Corella, 2011; Corella et al., 2011a). The increase in gypsum and Sr (Fig. 3) in the sediment suggests that lake waters were more concentrated than during the warmer mid-20th century.

\subsubsection{Lake Estanya}

The Balsas de Estanya karstic system $\left(42^{\circ} 02^{\prime} \mathrm{N}, 0^{\circ} 32^{\prime} \mathrm{E}\right.$, $670 \mathrm{~m}$ a.s.l.) is located at the foothills of the External Ranges, in the central-eastern Pre-Pyrenees (Fig. 1a). The sedimentary sequence has been dated by ${ }^{137} \mathrm{Cs} /{ }^{210} \mathrm{~Pb}$ and radiocarbon and spans the last $21 \mathrm{ka}$.

The multi-proxy analysis of sediment cores recovered in the distal areas of the main lake, including sedimentology, elemental and isotopic geochemistry and biological indicators (pollen, diatoms and chironomids) reveals arid conditions during the MCA followed by more positive water balances during the LIA, starting at $1300 \mathrm{AD}$ and lasting to 1850 AD. Consistently, pollen reflects warmer and drier conditions for the MCA, with a landscape dominated by junipers and Mediterranean elements, a relatively low abundance of mesophytes and a poorly developed aquatic component. The increase in water availability during the LIA is characterized by increase of riparian and hygrohydrophytes (Salix, Ulmus, Tamarix, Potamogeton, Myriophyllum, Nuphar, Lemna), and a recovery of mesophytes (Betula, Corylus, Alnus, deciduous Quercus, Abies) (Fig. 2, Table 1). Likewise diatom assemblages suggests low water levels and saline conditions during the MCA (Morellón et al., 2011).

A reconstruction of salinity, based on the results of Principal Component Analyses applied to the high-resolution geochemical dataset (see details in Morellón et al., 2011) identifies large hydrological fluctuations. Other biological proxies (diatoms, chironomids) and sedimentological indicators show a coherent evolution (Table 1, Fig. 3). The LIA in Estanya is characterized by complex internal fluctuations with increased water balance during the solar minima.

\subsubsection{Lake Montcortès}

Lake Montcortès $\left(42^{\circ} 19^{\prime} \mathrm{N}, 0^{\circ} 59^{\prime} \mathrm{E}, 1027 \mathrm{~m}\right.$ a.s.l.) is located $50 \mathrm{~km}$ north-east of Estanya (Fig. 1a). The composite sequence of Montcortès spans the last $5.3 \mathrm{ka}$ and constitutes the longest varved, annually resolved sequence recovered to date in the Iberian Peninsula (IP) (Corella, 2011; Corella et al., 2011b). The age model is particularly robust because of the combination of varve counting, ${ }^{210} \mathrm{~Pb}$ and radiocarbon dating.

The analysis of microfacies and sublayering of laminae revealed colder conditions during the LIA (1300-
1800 AD); (Corella, 2011). During this period, most of the calcite laminae show a fine-coarse sub-layering interpreted as a result of prolonged winter conditions with a delayed warming in spring, which may cause supersaturation leading to rapid nucleation of small calcite crystals. Higher Fe/Mn ratios also suggest more frequent and longer anoxic conditions at the hypolimnion (Corella, 2011), and increased abundance of planktic diatom Cyclotella cyclopuncta points to higher lake levels (Scussolini et al., 2011). The lack of diatom valves during the MCA is explained though the synergy of arid conditions and higher anthropogenic pressure on the lake. The presence of the Mediterranean scrub community reflects warmer conditions during the MCA, and its disappearance during the LIA in the 15th century, together with the increase in forest, are interpreted as colder and more humid conditions during the LIA (Rull et al., 2011). Towards the end of the LIA (ca. 1700 to $1900 \mathrm{AD}$ ) intermittent abundance of diatoms and occasional predominance of pennate, littoral taxa point to fluctuating lake levels; in more recent times, the presence of oligotrophic species marks the shift to poorer nutrient levels (Fig. 3).

\subsubsection{Lake Basa de la Mora}

Lake Basa de la Mora $\left(42^{\circ} 32^{\prime} \mathrm{N}, 0^{\circ} 19^{\prime} \mathrm{E}, 1914 \mathrm{~m}\right.$ a.s.l.) is a shallow, glacial-karstic lake located in the Cotiella Massif, in the Central-Eastern area of the Internal Ranges of the Pyrenees (Fig. 1a).

This radiocarbon-dated sedimentary sequence displays the highest resolution for the Holocene period in the region $\left(117 \mathrm{~cm} \mathrm{kyr}^{-1}\right)$. The multi-proxy analyses of sediment cores revealed more arid conditions in medieval times (9001300 AD), as indicated by: a rise in Juniperus, a decrease in mesophytes and aquatic plants and the highest percentages of heliophyte herbs (including Artemisia, although this taxum could also indicate the existence of anthropogenic activities in the area) (Table 1, Fig. 2), and a decreased in clastic input, represented by lower silicon (Si) content (Fig. 3). The MCA is also characterized by high organic and carbonate productivity related to a larger development of the palustrine area and, possibly, the lowest lake level of the last $2000 \mathrm{yr}$. During most of the LIA (1300-1750 AD), an opposite pattern occurs, leading to higher values of elements associated to detrital input due to an increase in runoff (Moreno et al., 2010; PérezSanz, 2009; Pérez-Sanz et al., 2011). Sedimentological and geochemical signatures for the last $200 \mathrm{yr}$ are coherent again with lower lake levels and drier climate conditions.

\subsubsection{Lake Redon}

Lake Redon $\left(42^{\circ} 38^{\prime} \mathrm{N}, 0^{\circ} 46^{\prime} \mathrm{E}\right)$ is located at a high altitude ( $2240 \mathrm{~m}$ a.s.1.) in the Maladeta batholith, an area characterized by low human impact (occasional sheep grazing in summer) (Fig. 1a). The age model of the sequence is based on ${ }^{210} \mathrm{~Pb}$ dating and 12 radiocarbon dates, covering the entire Holocene (Camarero et al., 1998). Chrysophytes cysts 


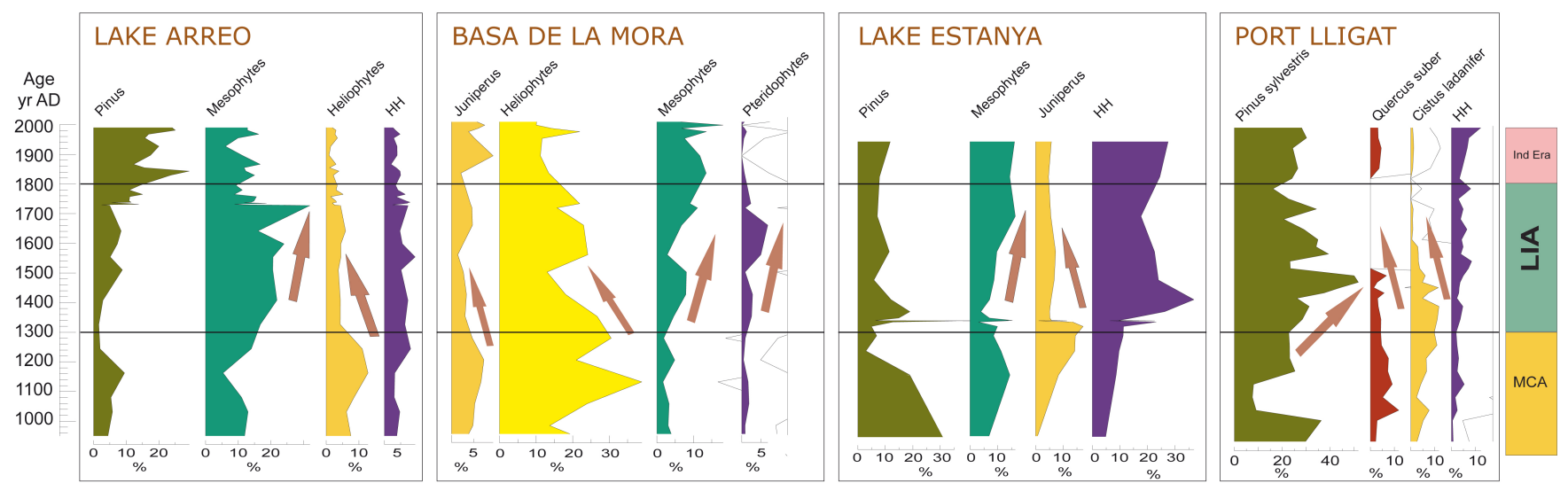

Fig. 2. Selected pollen taxa and group diagrams from lakes Arreo, Basa de la Mora, Estanya and Portlligat and correlation between them. In Arreo sequence Mesophytes curve is composed by deciduous Quercus, Fagus and Corylus; Heliophytes group by Artemisia, Chenopodiaceae, Asteraceae; and Hydro-hygrophytes includes Cyperaceae and Typha. In Basa de la Mora, Heliophytes group is formed by Ephedra distachya, E. fragilis, Artemisia, Cichorioideae, Asteroideae, Carduaceae, Chenopodiaceae, Plantago, and Heliamthemum; whereas Mesophytes comprise: deciduous Quercus, Alnus, Carpinus, Salix, Ulmus, Populus, Fraxinus and Juglans. Estanya groups of Mesophytes and Hydro-hygrophytes are composed by Betula, Corylus, Alnus, Tilia, Ulmus, Populus, Salix, Fagus, and deciduous Quercus; and Cyperaceae, Typha, Potamogeton, Myriophyllum, Nuphar and Lemna, respectively. Finally, Portlligat hydro-hygrophytes curve includes: Cyperaceae, Myriophyllum, Asplenium, Pteridophyta monolete and Pteridophyta trilete.

are used as proxies of winter-spring temperatures (Pla and Catalán, 2005) and diatoms for water alkalinity (Catalan et al., 2009), which eventually can be related to air temperature of the snow-free period (summer and autumn). For both proxies, transfer functions were developed, based on calibration sets of more than one hundred lakes. A recent study has confirmed the relationship between chrysophyte assemblages and winter-spring temperatures, as well as the mechanism behind it (Pla-Rabes and Catalan, 2011).

Interestingly, the two records did not show a parallel behaviour (Fig. 3). A decrease of snow period temperatures (winter-spring) would have started earlier than a similar decrease in snow-free period temperatures (summerautumn). While summer temperature was still high during 11th and 12th centuries, winter temperatures decreased sharply. According to the Redon record, summer cooling occurred abruptly by $1200 \mathrm{AD}$ and reached the lowest temperature values by $1700 \mathrm{AD}$. The snow period temperatures improved progressively from the 12 th century but showed cold phases in the 14th, 18th and early 20th centuries.

\subsubsection{Portlligat Bay}

Portlligat Bay $\left(42^{\circ} 17^{\prime} \mathrm{N} ; 3^{\circ} 17^{\prime} \mathrm{E}, 0 \mathrm{~m}\right.$ a.s.l. $)$ is a shallow (maximum depth, $7.1 \mathrm{~m}$ ) and small inlet located in the NE Mediterranean coast of the IP, connected to the sea (Fig. 1a). Pollen associations (López-Sáez et al., 2009) (Fig. 2) indicate relatively dry conditions and high temperatures during the MCA, following the drop of Pinus sylvestris formations and the development of Mediterranean taxa such as Cistaceae and Quercus suber. The sequence shows a different pattern of forest evolution during the LIA with higher percentages of
Pinus sylvestris and lower Mediterranean formations. These could be related to colder temperatures. Concentration of fungal ascospores Type 18 has been used for the reconstruction of humidity (Van Geel, 1978) and fluctuating but more humid conditions were reconstructed from $1250 \mathrm{AD}$ to the early 1800s (Table 1). Maximum humidity was reached from 1450 to $1550 \mathrm{AD}$, whereas the most arid conditions took place during the 19th and 20th centuries and additionally, during the MCA (1000-1150 AD) (López-Sáez et al., 2009) (Fig. 2).

\subsection{Dendroclimatological reconstructions}

\subsubsection{Gerber-Sobreestivo (GER-SOB) chronology}

Two timberline sites (GER and SOB) of similar ecological and climatic conditions were selected for this reconstruction (see Büntgen et al., 2008 for details). Samples include living and dry-dead pine trees (Pinus uncinata Mill.) of all age-classes. The Gerber site (GER) $\left(42^{\circ} 38^{\prime} \mathrm{N}, 1^{\circ} 60^{\prime} \mathrm{E}\right.$, 2200-2350 $\mathrm{m}$ a.s.l.) is located within the central-eastern part of the Pyrenees, whereas the Sobreestivo (SOB) site $\left(42^{\circ} 41^{\prime} \mathrm{N}, 0^{\circ} 06^{\prime} \mathrm{E}, 2300-2400 \mathrm{~m}\right.$ a.s.l.), is located $70 \mathrm{~km}$ west of the GER site (Fig. 1a). Temperature records from the Pic du Midi de Bigorre mountain observatory $\left(43^{\circ} 04^{\prime} \mathrm{N}\right.$, $0^{\circ} 09^{\prime} \mathrm{E}, 2862 \mathrm{~m}$ a.s.l.) were used for proxy calibration trials. Methodological details can be found in Büntgen et al. (2008). This annually resolved record of June-September temperature variations spans the 1260-2005 AD period, and thus constitutes the longest annually-resolved warm season temperature record for the Pyrenees. 


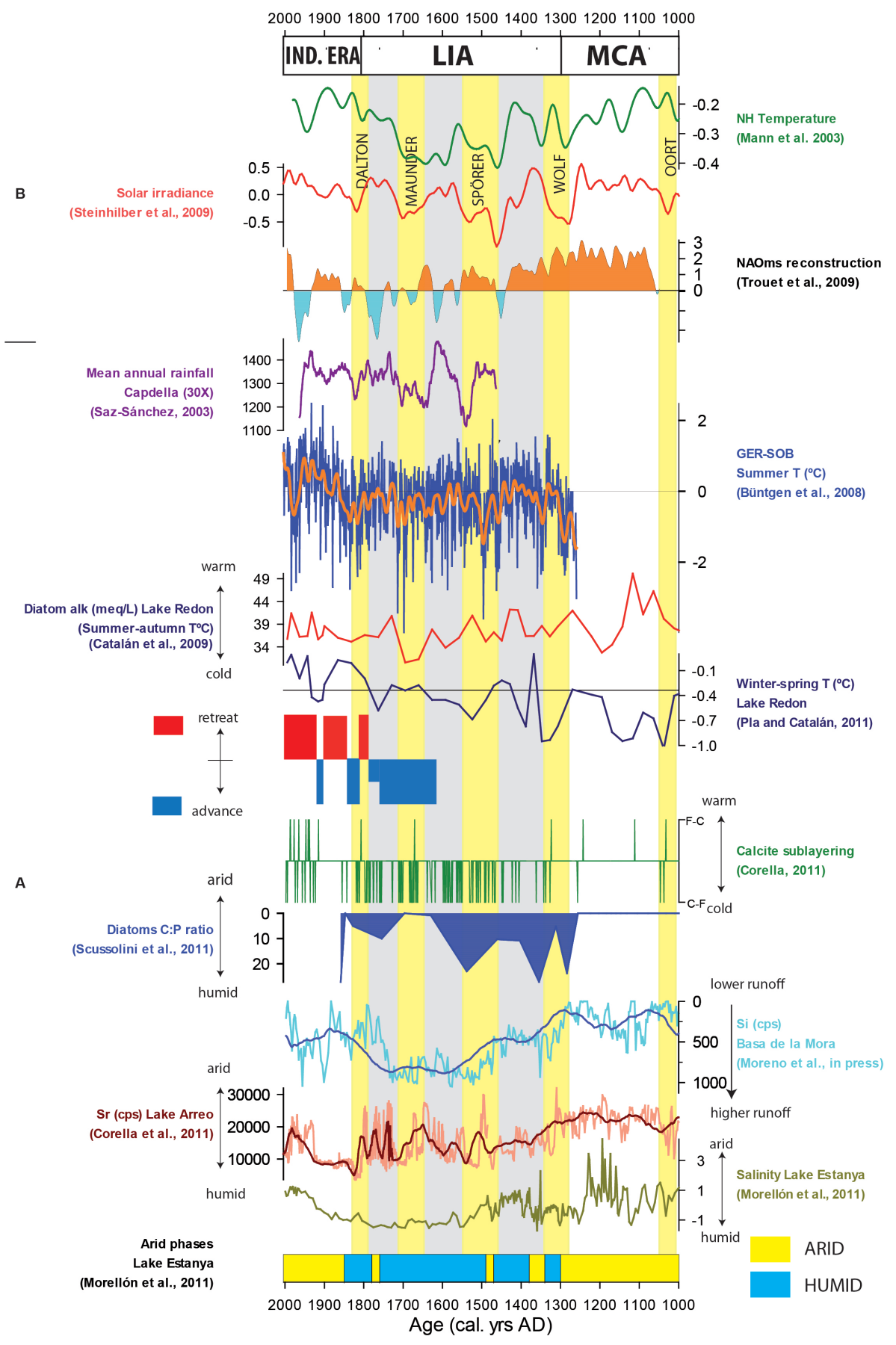

Fig. 3. (A) Selected records from the Southern Pyrenees reviewed in this paper, from top to bottom: Capdella tree-ring based mean annual rainfall (30× moving average) (Saz Sánchez, 2003), GER-SOB summer temperature tree-ring based reconstruction (original data and $20 \times$ moving average) (Büntgen et al., 2008), diatom alkalinity-based summer-autumn temperature and chrysophyte-based winter-spring temperatures reconstruction in Lake Redon (Pla and Catalán, 2005; Catalan et al., 2009), phases of advance and retreat of the Pyrenean glaciers (González Trueba et al., 2008), calcite sublayering (Fine-Coarse (F-C) or Coarse-Fine (C-F)) (Corella, 2011) and diatom C:P ratio (Scussolini et al., 2011) in Lake Montcortès, Si (cps) content in Lake Basa de la Mora (original data and 30× moving average) (Moreno et al., 2012), Sr (cps) content in Lake Arreo sequence (original data and 30× moving average) (Corella, 2011) and XRF-based salinity reconstruction and humid/arid phases in Lake Estanya (Morellón et al., 2011). (B) Supplementary regional and global records, from top to bottom: NH temperature reconstruction (Mann and Jones, 2003), solar irradiance (Steinhilber et al., 2009), and NAOms reconstruction (Trouet et al., 2009). Vertical yellow bars represent the chronology of the grand sunspot minima and temporal divisions Medieval Climate Anomaly (MCA), Little Ice Age (LIA) and Industrial Era (IND. ERA) are also indicated at the uppermost part of the figure. 
Table 1. Lacustrine and marine-littoral sequences from the Southern Pyrenees reviewed in this paper, including climate/hydrology and vegetation conditions recorded for the different chronological stages defined in this paper: Late MCA (1000-1300 AD), LIA (1300-1800 AD) and Post-LIA (after 1800 AD).

\begin{tabular}{|c|c|c|c|c|c|c|c|}
\hline \multirow[t]{3}{*}{ Site and location } & \multirow[t]{3}{*}{ Type } & \multicolumn{6}{|c|}{ Environmental conditions } \\
\hline & & \multicolumn{2}{|c|}{ Late MCA (1000-1300 AD) } & \multicolumn{2}{|c|}{ LIA (1300-1800 AD) } & \multicolumn{2}{|c|}{ Post-LIA (after $1800 \mathrm{AD}$ ) } \\
\hline & & $\begin{array}{l}\text { Hydrology/ } \\
\text { Climate }\end{array}$ & Vegetation & $\begin{array}{l}\text { Hydrology/ } \\
\text { climate }\end{array}$ & Vegetation & $\begin{array}{l}\text { Hydrology/ } \\
\text { climate }\end{array}$ & Vegetation \\
\hline $\begin{array}{l}\text { Arreo } \\
42^{\circ} 46^{\prime} \mathrm{N} \\
2^{\circ} 59^{\prime} \mathrm{W} \\
655 \mathrm{~m} \text { a.s.l. }\end{array}$ & Lake & $\begin{array}{l}\text { Low lake levels, } \\
\text { high salinity, } \\
\text { Holomictic } \\
\text { conditions }\end{array}$ & $\begin{array}{l}\text { Fall in mesophytes, } \\
\text { mainly decidu- } \\
\text { ous Quercus and } \\
\text { development of } \\
\text { ruderals, meadows } \\
\text { and pastures. }\end{array}$ & $\begin{array}{l}\text { High lake levels, } \\
\text { Lower salinity, } \\
\text { Meromictic condi- } \\
\text { tions }\end{array}$ & $\begin{array}{l}\text { Deciduous forest } \\
\text { recovery (mainly } \\
\text { Quercus sp. and } \\
\text { Fagus). Decrease } \\
\text { in human activities } \\
\text { (meadows and } \\
\text { pastures). }\end{array}$ & $\begin{array}{l}\text { Low lake levels, } \\
\text { higher salinity, } \\
\text { Holomictic } \\
\text { conditions }\end{array}$ & $\begin{array}{l}\text { Deforestation of } \\
\text { oak and beech } \\
\text { forest and devel- } \\
\text { opment of Pinus } \\
\text { formations (includ- } \\
\text { ing recent Pinus } \\
\text { radiata cultivation) }\end{array}$ \\
\hline $\begin{array}{l}\text { Estanya } \\
42^{\circ} 02^{\prime} \mathrm{N} \\
0^{\circ} 32^{\prime} \mathrm{E} \\
670 \mathrm{~m} \text { a.s.l. }\end{array}$ & Lake & $\begin{array}{l}\text { Low lake levels, } \\
\text { High salinity, } \\
\text { variable runoff }\end{array}$ & $\begin{array}{l}\text { Increase of } \\
\text { Juniperus and } \\
\text { Mediterranean } \\
\text { taxa. Reduced } \\
\text { proportions and } \\
\text { variety of aquatic } \\
\text { plants. }\end{array}$ & $\begin{array}{l}\text { Higher lake levels, } \\
\text { lower salinity, } \\
\text { variable runoff }\end{array}$ & $\begin{array}{l}\text { Development of } \\
\text { Mesophytes, peak } \\
\text { of Pinus nigra } \\
\text { type, and increase } \\
\text { of aquatic taxa. }\end{array}$ & $\begin{array}{l}\text { High lake levels, } \\
\text { higher salinity, } \\
\text { Reduced runoff }\end{array}$ & $\begin{array}{l}\text { Recovery of open } \\
\text { mixed Mediter- } \\
\text { ranean/deciduous } \\
\text { formations with } \\
\text { Pine. Maximum } \\
\text { expansion of } \\
\text { cultivated areas }\end{array}$ \\
\hline $\begin{array}{l}\text { Montcortès } \\
42^{\circ} 19^{\prime} \mathrm{N} \\
0^{\circ} 59^{\prime} \mathrm{E} \\
1027 \mathrm{~m} \text { a.s.l. }\end{array}$ & Lake & $\begin{array}{l}\text { Warm conditions, } \\
\text { reduced anoxia, } \\
\text { higher runoff }\end{array}$ & $\begin{array}{l}\text { Establishment of } \\
\text { Mediterranean } \\
\text { shrubland with } \\
\text { increase in ever- } \\
\text { green Quercus and } \\
\text { decrease of pines. } \\
\text { Development of } \\
\text { cultivated taxa. }\end{array}$ & $\begin{array}{l}\text { Cold conditions, } \\
\text { Higher anoxia, } \\
\text { lower runoff }\end{array}$ & $\begin{array}{l}\text { Increase in AP for- } \\
\text { mations, specially } \\
\text { conifers and decid- } \\
\text { uous taxa. De- } \\
\text { crease in shrubland } \\
\text { and heliophytes. }\end{array}$ & $\begin{array}{l}\text { Warm conditions, } \\
\text { lower anoxia, } \\
\text { higher runoff. }\end{array}$ & $\begin{array}{l}\text { Expansion of } \\
\text { conifer formations } \\
\text { and anthropogenic } \\
\text { influenced areas } \\
\text { (mainly pastures } \\
\text { with ruderals). }\end{array}$ \\
\hline $\begin{array}{l}\text { Basa de la mora } \\
42^{\circ} 32^{\prime} \mathrm{N} \\
0^{\circ} 19^{\prime} \mathrm{E} \\
1904 \mathrm{~m} \text { a.s.l. }\end{array}$ & Lake & $\begin{array}{l}\text { High carbonate } \\
\text { precipitation, } \\
\text { decreased runoff }\end{array}$ & $\begin{array}{l}\text { Development of } \\
\text { Juniperus and } \\
\text { heliophytes and } \\
\text { decrease in all } \\
\text { deciduous taxa. }\end{array}$ & $\begin{array}{l}\text { Lower } \\
\text { carbonate } \\
\text { precipitation, } \\
\text { higher clastic input }\end{array}$ & $\begin{array}{l}\text { Fall in Juniperus } \\
\text { and heliophytes } \\
\text { and increase } \\
\text { in Mesophytes and } \\
\text { Pteridophytes. }\end{array}$ & $\begin{array}{l}\text { High carbonate } \\
\text { precipitation, } \\
\text { decreased runoff }\end{array}$ & $\begin{array}{l}\text { Recovery of mixed } \\
\text { conifer (Pinus and } \\
\text { Juniperus) / decid- } \\
\text { uous taxa } \\
\text { formations. }\end{array}$ \\
\hline $\begin{array}{l}\text { Redon } \\
42^{\circ} 38^{\prime} \mathrm{N} \\
0^{\circ} 46^{\prime} \mathrm{E} \\
2240 \mathrm{~m} \text { a.s.l. }\end{array}$ & Lake & $\begin{array}{l}\text { Higher summer- } \\
\text { autumn tempera- } \\
\text { tures Lower } \\
\text { winter-spring } \\
\text { conditions }\end{array}$ & - & $\begin{array}{l}\text { Lower summer- } \\
\text { autumn tempera- } \\
\text { tures Relatively } \\
\text { low winter-spring } \\
\text { temperatures }\end{array}$ & - & $\begin{array}{l}\text { Relatively high } \\
\text { summer-autumn } \\
\text { temperatures } \\
\text { High winter-spring } \\
\text { temperatures }\end{array}$ & - \\
\hline $\begin{array}{l}\text { Portlligat } \\
42^{\circ} 17^{\prime} \mathrm{N} \\
3^{\circ} 17^{\prime} \mathrm{E} \\
0 \mathrm{~m} \text { a.s.l. }\end{array}$ & $\begin{array}{l}\text { Shallow } \\
\text { marine }\end{array}$ & - & $\begin{array}{l}\text { Increase in Quer- } \\
\text { cus suber, de- } \\
\text { ciduous Quer- } \\
\text { cus forests and } \\
\text { Mediterranean } \\
\text { shurblands (Cistus } \\
\text { ladanifer) }\end{array}$ & - & $\begin{array}{l}\text { Expansion of Pinus } \\
\text { sylvestrys and re- } \\
\text { duction in Quercus } \\
\text { suber and Mediter- } \\
\text { ranean shrublands }\end{array}$ & - & $\begin{array}{l}\text { Recovery of Quer- } \\
\text { cus suber and } \\
\text { deciduous Quercus } \\
\text { forests in mixed } \\
\text { formations with } \\
\text { conifers }\end{array}$ \\
\hline
\end{tabular}

Relatively high summer temperatures were reconstructed during most of the 1300-1500 AD period and the 20th century, separated by a rather prolonged cooling from around 1500 to $1850 \mathrm{AD}$, within the LIA (Fig. 3). The six warmest decades occurred during the 20th century and the following four warmest during the period 1360-1440 AD (Büntgen et al., 2008).

\subsubsection{Capdella record}

Five chronologies from several sites in the Southern Pyrenees were used for this reconstruction: Aigües Tortes and Larra, obtained from Pinus uncinata $R$. samples, and Pinobajo, Trapa and Ibonciecho, from Pinus sylvestris (Saz Sánchez, 2003). Standard techniques were applied for the sampling, construction of chronologies and reconstruction of climatic variables (Fritts, 1990). Among 20 and 25 samples were extracted from living trees to construct each chronology. Treerings widths were measured with a resolution of $0.01 \mathrm{~mm}$ using an ANIOL measuring table (Aniol, 1983). Absolute dating of tree rings was checked by program COFECHA (Holmes, 1986). ARSTAN was used to standardize ringwidth measures in order to eliminate low frequency non climatic signal and to combine standardized indices into 
site chronologies (Cook and Kairiukstis, 1990). Rainfall records from Capdella weather station $\left(42^{\circ} 28^{\prime} \mathrm{N}, 0^{\circ} 59^{\prime} \mathrm{E}\right.$, $1407 \mathrm{~m}$ a.s.l.) were used for proxy calibration. Finally, using PRECON (Fritts and Shashkin, 1995) chronologies and climatic data were calibrated in order to obtain a response function. Methodological details can be found in Saz Sánchez (2003) and Chueca Cía et al. (2005) (Fig. 3). The reconstructed precipitation shows relatively higher values than in recent times for the last $500 \mathrm{yr}$, with several marked decade - long humid periods around 1500, 1600, $1700 \mathrm{AD}$ and the early 20th century; with relative rainfall minima centred at ca. $1800 \mathrm{AD}, 1900 \mathrm{AD}$ and an abrupt decreasing trend during the late 20th century.

\subsection{Evidence of glacier fluctuations}

Extensive research carried out by González-Trueba et al. (2008) demonstrated that glaciers occurred in more than 20 different massifs of the Pyrenees during the LIA, with a wide range of mean equilibrium line altitudes (ELAs) above and between $2650 \mathrm{~m}$ a.s.l. in the oceanic-influenced massifs (Balaitous and Infierno massifs among others) and $2900 \mathrm{~m}$ a.s.l. in the continental massifs (Maladeta and Posets massifs among others). Thirteen massifs with glaciers were considered relevant for this study (Fig. 1b). The most common aspect was the development of cirque glaciers with reduced or absent tongues. This study is based on geomorphologic and morphostratigraphical surveys and historical archives and demonstrates the rapid response of these ice bodies to climatic variations.

The historical maximum extent of glaciers in the Pyrenees took place between 1600 and $1750 \mathrm{AD}$, followed by a retreat during the next $50 \mathrm{yr}$, alternating with minor readvances responsible for the development of numerous small moraines (Fig. 3). A secondary advance, characterized by a rapid, short-lived growth of ice bodies occurred during the 19 th century, lasting until the 1920s. The temperatures estimated from the lowering of the ELAs are $0.7-0.9^{\circ} \mathrm{C}$ colder than present-day conditions in this area. A generalized phase of glaciers retreat occurred since the 1870 s, with minor readvances during the last decades of the 19th century and the 1920s. Since then, glaciers underwent a continuous retreat, becoming ice patches in most of the cirques affected by LIA glaciations, with minor expansions in 1945 and 1964 AD in the French slopes. Since the 1970s-1980s, a drastic retreat started, continuing till the present (Fig. 3) (González Trueba et al., 2008).

\section{Millennium-long environmental changes in the Southern Pyrenees}

\subsection{Evaluation of the reviewed records}

Selected records from the Southern Pyrenees, including lacustrine and marine-littoral sequences, dendroclimatological records, and reconstructions of glacier fluctuations, provide evidence of a broadly consistent pattern of climatic fluctuations during the last millennium. Nevertheless, before comparing these records, the differences in chronological resolution and climate sensitivities of each type of sequence and proxies must be evaluated (North et al., 2006).

Tree rings provide annually resolved records and are sensitive to high-frequency climate fluctuations (Briffa, 2000). The two sequences reviewed in this paper respond to both temperature fluctuations (GER-SOB) and rainfall variability (Capdella). These two high-resolution sequences start at ca. 1260 and $1460 \mathrm{cal}$ yr BP, respectively, which limits their record to intra-LIA (1300-1800 AD) variability and the transition between the LIA and recent warming (after $1800 \mathrm{AD}$ ). In contrast, lake sequences comprise the whole studied time interval and allow comparison with previous MCA, but they generally have radiocarbon-based chronologies characterized by a lower resolution, and able to capture only lower frequency variability (multi-decadal to centennial). Karstic lakes reviewed in this paper are particularly sensitive to changes in the hydrological balance (precipitation minus evaporation) reflected by different inorganic and biological proxies, as outlined in the previous section. Only lakes Arreo and Montcortès have varved (i.e. annual) chronologies able to record higher-frequency fluctuations. Changes in sublayering in Montcortès calcite laminae reflect relative changes in water temperature (colder or warmer stages). Accordingly, higher density of Fine-Coarse (F-C) sublayering through this record are interpreted as periods of predominantly colder conditions.

Lake Redon also provides information about thermal conditions not only as relative changes (summer-autumn) but also as a semi-quantitative estimation (winter-spring), inferred from biological proxies. The chronological control is robust, obtained by combining different radiometric techniques $\left({ }^{137} \mathrm{Cs},{ }^{210} \mathrm{~Pb},{ }^{14} \mathrm{C}\right)$, but because of the comparatively lower sedimentation rate of this sequence the chronological resolution is relatively low and variable. In spite of these limitations, visual comparison of reconstructed summerautumn temperatures reflects a relatively good match with the main trends in summer temperatures recorded in GERSOB (Fig. 3). The relative maximum winter-spring temperatures reconstructions also coincide with and major episodes of glacier retreat (1750-1900 and after the 1920s). Only the early 19th century glacier advance was not coincident with a winter temperature drop in Redon.

Glaciers in Mediterranean mountains are characterized by a high sensitivity to climate variability (Hughes, 2010), but the relatively short time span of the Pyrenean records (from ca. $1600 \mathrm{AD}$ to the present) and their relatively lower chronological resolution are major shortcomings when comparing to other records. As expected, reconstructed fluctuations show a broadly consistent pattern with temperature and hydrological changes inferred from other records and major advances are coincident with more positive water balances and colder conditions. 
Pollen records from lake sequences are subject to the same chronological uncertainties derived from radiocarbon dating. Despite the impact of anthropogenic activities, previous research on these sequences has demonstrated the reliability of pollen as a proxy of climate fluctuations (Moreno et al., 2008, 2010; Morellón et al., 2011; Pérez Sanz et al., 2011). The proportion between xerophytic and Mediterranean components and mesophytes, whose development is favoured under drier and more humid conditions, respectively, reflects changes in the regional hydrological conditions at a centennial timescale (Fig. 2). The coincidence of changes in the terrestrial vegetation components, aquatic taxa and other non-palynological proxies provides further support for this hypothesis. The geographical location of each of these pollen sequences determines differences in local vegetation, with an increasing content of Mediterranean elements towards the east and the south. These differences have also been taken into account for the selection of taxa indicative of dry conditions in each case: herbaceous heliophyte taxa (westernmost lake Arreo), heliophytes and junipers (Central Pyrenees: Basa de la Mora and Estanya) or other Mediterranean taxa such as Cistus (easternmost Portlligat site) (Figs. 1a and 2).

Comparison among these sequences and correlation with other regional and global records enable us to investigate the timing, intensity and chronology of the main environmental changes occurring prior, during and after the LIA and their relationship with climatic forcing mechanisms (Fig. 3). The overall good agreement of a wide range of records with different locations and altitudes, likely subjected to variable human activity, suggests that they respond to common climatic forcings.

\subsection{The last phases of the MCA}

In agreement with the rest of the IP (Moreno et al., 2012, 2011), generally arid conditions have been reconstructed for the last phases of the MCA (1000-1200 AD) in the Pyrenees. Lower lake levels and higher salinity occurred in lakes Arreo, Estanya, and Montcortès. Relatively low clastic input, reflecting decreased runoff caused by less precipitation also occurred in Basa de La Mora. Pollen associations in these sites and Portlligat Bay (Fig. 2) also indicate dry conditions with the development of the xerophytic and Mediterranean component (Juniperus and heliophyte herbs increase, evergreen Quercus increased while deciduous Quercus decreased), a decrease in mesophytes and the aquatic component. Despite spatial differences and the human influence on these watersheds, drier conditions can be interpreted for the MCA (Moreno et al., 2012).

Only two records provide indirect information about thermal conditions during this period. An increase in the calcite laminae thickness in Lake Montcortès indicates generally warmer conditions compared with the subsequent LIAassociated cooling. The discrepancy in lake Redon re- constructions with the occurrence of higher but variable summer-autumn temperatures in Redon (Catalan et al., 2009) (Fig. 3) and the lowest winter temperatures (Pla and Catalán, 2005) would be explained as a reflection of the strong seasonality during this period.

\subsection{The LIA}

Higher lake levels and hence, moister conditions started ca. $1300 \mathrm{AD}$ in lakes Arreo, Estanya and Montcortès. An increase in sediment delivery and runoff also occurred at this time in Basa de la Mora (Fig. 3). Pollen associations from Basa and Estanya sequences show a general decline of xerophytes and Mediterranean taxa (Juniperus, evergreen Quercus), some expansion of deciduous trees (mesophytes) and a rise of the aquatic content (Potamogeton increase). Arreo and Montcortès vegetation composition show similar patterns of changes. The Portlligat Bay sequence also suggests the start of a humid period, even though mediated by higher human induced fires and an increase of cattle raising, resulting in a change to mesotrophic conditions (López-Sáez et al., 2009) (Table 1, Fig. 2).

The increase in stream flow activity in the alluvial systems of the Central Ebro Basin, whose headwaters are located in the Pyrenees, also indicate increased water availability during this period (Sancho et al., 2007; Constante et al., 2011). An increased number of flood events was also recorded in the nearby Ebro watershed after $1300 \mathrm{AD}$ (Benito et al., 1996). The occurrence of predominantly humid conditions during the LIA has been widely detected elsewhere in the IP (Moreno et al., 2012): (i) higher lake levels were reconstructed in the north (e.g. La Cruz Lake, Iberian Range (Julià et al., 1998)) and in the south of Spain (Martín-Puertas et al., 2008, 2010), (ii) increased continental runoff reconstructed from marine sequences (e.g. Nieto-Moreno et al., 2011), (iii) increased Westerlies in the W Mediterranean (Moreno et al., 2012), (iv) increased storm activity in the nearby French Mediterranean Coast (Dezileau et al., 2011) and (v) more frequent floods in the Tagus headwaters (Moreno et al., 2008; Benito et al., 2003). Accordingly, increased water availability has been reconstructed in other areas of the W Mediterranean, such as Morocco (Détriché et al., 2009; Esper et al., 2007) and in the Alps (Magny et al., 2008, 2010).

The onset of the fine-to-coarse sublayering in the calcite laminae of Lake Montcortès, interpreted as a dominance of lower temperatures, occurred after ca. 1350 AD (Corella, 2011), coinciding with colder conditions in Lake Redon, both in winter and summer temperatures (Pla and Catalán, 2005; Catalan et al., 2009). Other evidence of widespread colder conditions in the region come from the neighbouring regions of Landes and Aquitaine (SW France) were loess deposits occurred from 0.8 to $0.2 \mathrm{ka} \mathrm{BP}$ (Bertran et al., 2011). The lack of temperature data from GER-SOB dendroclimatic reconstruction prior to $1300 \mathrm{AD}$ makes it difficult to attribute an exact date to the onset of cold conditions associated with 
the LIA. In fact, Büntgen et al. (2008) reconstructed the four warmest decades of pre-industrial times during the period 1360-1440 AD, which indicates the predominance of relatively mild thermal conditions during the first part of the LIA. However, a drop in temperatures occurred during the mid to late 15th century, consistent with a decrease in winter temperatures in Redon.

Other indirect evidence of temperature changes also indicate that the coldest conditions of the LIA in NE Iberian Peninsula did not take place until the 16th-19th centuries. As an example, the Ebro River (Fig. 1a), fed by many tributaries from the Southern Pyrenees, froze near its mouth in the town of Tortosa (Tarragona), 17 times since ca. $1400 \mathrm{AD}$ (Puente, 2007). According to historical reports (Benito et al., 1996), the maximum frequency of frost episodes and intensity occurred between the 16th and 18th centuries. Historical reports also document colder conditions in the IP between the 16th and 19th centuries (Font-Tullot, 1986), with minimum temperatures during the 17th century. Accordingly, maximum (recent) glacier advances in the Southern Pyrenees took place from 1600 to $1750 \mathrm{AD}$, leading to a slower development during the late 18th and early 19th century. The chronology of this phase coincides with reconstructions for the European Alps (Schaefer et al., 2009). However, Calderone Glacier in Gran Sasso Massif (Italy), one of the southernmost glaciers in Mediterranean Europe, experienced a minor advance in the period 1313-1373 AD, prior to a maximum advance later on during the LIA, coinciding with higher lake levels in lakes Acessa and Fucino centered around 500 cal yr BP (Giraudi et al., 2011). In spite of the occurrence of cold and humid conditions along the LIA, glacier advances required a combination of high winter precipitation and low summer temperatures (Paasche and Bakke, 2010). According to this dataset, these two conditions were probably not fulfilled during the early phases of the LIA in the Pyrenees, between 1300 and 1600 AD. Coldest summer temperatures, accompanied by relatively cold winter conditions in Redon occurred from 1500 to $1700 \mathrm{AD}$. Consistently, the most humid conditions, indicated by minimum salinity and maximum lake levels and/or clastic input, were not reached until the period 1500-1600 AD (Fig. 3) and maximum precipitation in Capdella was recorded by tree rings ca. $1600 \mathrm{AD}$ (Saz Sánchez, 2003) (Fig. 3). Flood records also show an increase in the number of events in Ebro Basin and in the Eastern Pyrenean rivers after 1600 AD (Benito et al., 1996).

In summary, we can broadly identify two major phases of environmental change that occurred during the LIA in the Southern Pyrenees: (i) a transitional phase MCA-LIA, characterized by fluctuating, moist conditions and relatively cold temperatures, between ca. 1300 and $1600 \mathrm{AD}$; and (ii) a second period, extending from ca. 1600 to $1800 \mathrm{AD}$, characterized by lower temperatures and higher water availability, leading to maximum glacier advances. In spite of the predominance of cold and humid conditions along the LIA, a lower amplitude hydrological and thermal internal variabil- ity was recorded in most of the sites (Fig. 3), as discussed below.

\subsection{LIA to recent warming transition}

An aridification trend started synchronously in lakes Arreo, Estanya, Montcortès and Basa de la Mora after ca. 1800 AD. Higher water concentration and/or more frequent oxic conditions in these settings indicate lower lake levels and decreased water balance. Pollen records show a new increase of human pressure and no aridity trends can be clearly extracted. Nevertheless, humidity reconstruction based on nonpollen palynomorphs in Portlligat indicates an abrupt decrease starting ca. $1750 \mathrm{AD}$, coinciding with an abrupt reduction of Castanea and Vitis culture while cereal cultivation is completely interrupted; the percentage of several arboreal elements (Fagus, Abies, Corylus, Quercus suber type) are also reduced or even disappear.

Decreased water availability has been also recorded in lakes in the North of the IP (e.g. Taravilla (Moreno et al., 2008), Lake Enol (López-Merino et al., 2012) and S Spain, (e.g. Doñana (Sousa and García-Murillo, 2003); Lake Zoñar (Martín-Puertas et al., 2008)). Marine cores around the IP also documented reduced river input associated with lower runoff (e.g. Nieto-Moreno et al., 2011). A similar hydrological response was detected in other areas of the $\mathrm{W}$ Mediterranean, like the French Jura (Magny et al., 2008) or Morocco (Détriché et al., 2009). However, Capdella tree ring sequence display a more complex variability, characterized by relative rainfall minima centred at ca. $1800 \mathrm{AD}, 1900 \mathrm{AD}$ and an abrupt decreasing trend during the late 20th century (Fig. 3).

Temperatures started to rise at the same time, between 1800 and $1850 \mathrm{AD}$, according to GER-SOB record, reaching their maximum values during the 20th century. Dendroclimatological reconstructions carried out in Morocco also show an increase in aridity after the mid-20th century (Esper et al., 2007). A change in calcite sublayering also occurred in Montcortès at this time pointing in the same direction (Fig. 3). Consistently with this general trend glaciers started to retreat continuously after $1850 \mathrm{AD}$ (Fig. 3). Glacier readvances in the Pyrenees occurred between the last decades of the late 19th century and the 1920s (González Trueba et al., 2008) and have also been documented in other Mediterranean areas, like the Apennines (Giraudi, 2005), the Balkans (Hughes, 2010), Sierra Nevada (Gómez Ortiz et al., 2002, 2009), or the Cantabrian Mountains (González-Trueba, 2006, 2007; Serrano et al., 2011). Interestingly, this episode correlates with lower winter temperatures at Lake Redon (Pla and Catalán, 2005), a relative maximum in precipitation recorded in Capdella and a relative temperature minima in the GER-SOB records (Fig. 3) and globally with a decrease in NAO values during the early 20th century (Trouet et al., 2009). The onset of more arid conditions reconstructed for lake sediments in 
Arreo occurred right afterwards, since 1870 AD. Finally, a further decrease in temperatures occurred in the mid-20th century, as documented by GER-SOB and Redon records. Minor glacier stabilisation phases described by GonzálezTrueba et al. (2008) might also be related to this short-lived climate deterioration phase, in the frame of a generalized warming trend.

\section{Regional context and paleoclimatic implications of the LIA in the Pyrenees}

Temperature fluctuations in the Southern Pyrenees display a similar pattern compared to other reconstructions from Central Europe (Büntgen et al., 2010a), the Mediterranean Basin (Camuffo et al., 2010) and with other Northern Hemisphere palaeoclimate records at centennial timescales (e.g. Jones et al., 1998; Mann and Bradley, 1999), showing consistency with changes in solar activity (Steinhilber et al., 2009; Bard et al., 2000; Vaquero et al., 2002), global temperature fluctuations (Mann et al., 2008) and NAO index (Trouet et al., 2009). Comparison of climate records and volcanic activity (Gao et al., 2008) does not show a clear pattern in the Southern Pyrenees. On the one hand, some climate records show the expected cooling after volcanic eruptions, for example after the eruption of Tambora in $1815 \mathrm{AD}$. On the other hand, the largest eruption in the past $1500 \mathrm{yr}$ (about 2.5 times larger stratospheric sulphate injection than Tambora) of an unknown volcano in the $1258 \mathrm{AD}$ does not show up in any of the analysed climate records. Both low solar activity and volcanic eruptions lead to surface cooling compared with solar activity and no volcanic eruptions. In the past $1000 \mathrm{yr}$ these eruptions coincided with times of low solar activity as, e.g. during the LIA and only a few of them occurred during the MCA, when solar activity was relatively high. Thus, reconstructed colder conditions are interpreted as a result of low solar activity partly influenced by volcanic eruptions.

\subsection{The footprint of solar activity}

In spite of the limited chronological resolution of most of the records, derived from radiocarbon dating, several oscillations in the hydrological and thermal dynamics of the reviewed sequences during the LIA suggest that colder temperatures and at least, more positive water balances and/or increased runoff dominated during periods of diminished solar activity, the so-called grand solar minima.

Contrasting patterns have been recorded for the Oort Minimum (1010-1050 AD): although lower winter and summer temperatures were recorded in Lake Redon and relatively more humid conditions were reconstructed in Arreo, variable conditions occur in the rest of the lakes (Estanya, Montcortès and Basa de la Mora). However, during the Wolf Minimum (1282-1342 AD) all lakes experienced more humid conditions, evidenced by increased lake levels, lower water concentration and/or increased sediment delivery. Al- though Portlligat Bay has recorded more humid conditions in the Eastern Pyrenees during the LIA, in contrast to drier environments during the MCA, no significant hydrological response occurs for this solar minimum. In agreement with the expected pattern, an abrupt decrease in temperature was recorded in tree-ring based reconstructions of GER-SOB and higher altitude (colder) conditions occurred in Lake Redon (Fig. 3).

Colder conditions also occurred in the Pyrenees during the Spörer Minimum (1460-1550 AD), as indicated by lower temperatures in GER-SOB dendroclimatic reconstruction, calcite sublayering in Montcortès and lower winter temperature in Redon. Interestingly, within this phase, lasting for almost $100 \mathrm{yr}$ (1460-1550 AD), generally recorded as a relatively humid period, all the lacustrine sequences reviewed in this paper show a short lived reversed pattern (more negative water balance) centred around $1500 \mathrm{AD}$. Higher mean annual rainfall was also recorded in Capdella tree-ring sequence, with an abrupt decrease in precipitation at the end of this phase. During the Maunder Minimum (1645-1715 AD), reduced summer temperatures were recorded both in GERSOB and Redon, coinciding with a major phase of glacier advances. Most of the lake sequences clearly evidence higher effective moisture and/or increased runoff. However, the easternmost records of the region reviewed in this paper (Montcortès, Portlligat) show a less clear response, probably due to particular, local conditions. Mean annual rainfall reconstructed from Capdella also shows a relative maximum, less evident than the one corresponding to the Spörer Minimum (Fig. 3). In contrast, a clear temperature drop becomes evident in GER-SOB towards the end of the Dalton Minimum (1790-1830 AD), coinciding with a series of volcanic eruptions at the beginning of the 19th century, and contemporaneous to a short phase of glacier advances, also recorded in the Pyrenees. The short duration of the Dalton Minimum event (ca. $40 \mathrm{yr}$ ) and the low resolution of the age models might be responsible for contrasting responses reconstructed from the lake sequences.

Although most of the reviewed sequences display colder and more humid conditions during the grand solar minima, the intensity of the environmental response is highly variable. The influence of volcanic eruptions, other regional and local climate mechanisms and/or human influence might be responsible for this. Additionally, the variable chronological resolution of these records in some cases (e.g. lacustrine sequences, glacier fluctuations) limits a more precise correlation with this high-frequency climate variability. This environmental response disagrees with proposed patterns for the Western Mediterranean (Fletcher and Zielhofer, in press), but it is consistent with results obtained in Central European lakes (e.g. Magny et al., 2008, 2011a), likely indicating a high influence of local conditions and other as yet undetermined climate mechanisms. 


\subsection{Hydrological variability and the potential influence of the NAO}

Centennial-scale hydrological fluctuations in the Southern Pyrenees appear to be in phase with the NAO reconstruction (Trouet et al., 2009) for the last millennium. In agreement with most of the IP (Moreno et al., 2011), arid conditions prevailed during the MCA, when reconstructed NAO values were predominantly positive (Trouet et al., 2009), as a result of a positive radiative forcing (Shindell et al., 1999) (Fig. 3). During the instrumental period, there is clear evidence of interannual precipitation variations in the $\mathrm{W}$ Mediterranean area, with the highest positive rainfall anomaly located over $\mathrm{N}$ Iberia at the mean time as high pressure is dominant in $\mathrm{N}$ Europe (Cullen and deMenocal, 2000). Negative rainfall anomalies during the MCA and vice-versa during the LIA for the W Mediterranean region have been also reproduced by gridded high-resolution precipitation reconstructions (Pauling et al., 2006) and ECHO-G model simulations (Liu et al., 2009). Widespread proxy evidences for this centennial-scale pattern also exist (Graham et al., 2011). In spite of the complex spatial heterogeneity and the influence of other climate variability patterns, the NAO strongly affects the precipitation events in most parts of the IP (Trigo et al., 2004). Furthermore, correlation maps between NAO and winter precipitation over the IP for the period 1950-1990 reproduced by models display particularly high negative values for the Southern Pyrenees within the IP (Gómez-Navarro et al., 2011).

Accordingly, hydrological patterns reconstructed from the reviewed lake sequences agree on centennial timescales, reproducing this transition from arid conditions during the MCA into higher humidity during the LIA (Fig. 3). However, lake records show an increase in water levels starting at ca. $1300 \mathrm{AD}$, whereas, although NAO values show a decreasing trend after the MCA, most negative values are not reached until $1600 \mathrm{AD}$. Increased water availability recorded in lakes during the period 1300-1600 AD might have been amplified by increased aquifer recharge, resulting from reduced evaporation and thus, more positive water balance driven by lower temperatures during the LIA (e.g. Cacho et al., 2010, and references therein). Glacier maximum development in both northern and southern slopes coincides with this coldest and most humid period of the LIA in the Southern Pyrenees (1600-1800 AD) and displays a similar pattern compared to other Mediterranean mountains, like the Apennines (Giraudi, 2005) and the Balkans (Hughes, 2010). At lower timescales, some of the relative maxima in precipitation recorded in the Capdella tree-ring rainfall reconstruction during the last ca. $600 \mathrm{yr}$ correlate with negative reconstructed NAO-values.

Main phases of environmental change during the last millennium are synchronous at a regional scale with most of the Iberian Peninsula (Moreno et al., 2011) and also can be recognized across the Western Mediterranean area (Fletcher and Zielhofer, 2012). Exceptions to this pattern occur in the northwestern Atlantic shore of the IP (Ría de Muros, (Lebreiro et al., 2006; Galop et al., 2011) and Ría de Vigo (Kanner et al., 2012)) and also in South (Martín-Puertas et al., 2011), revealing an intra-regional complex variability in the hydrological conditions within the IP (Moreno et al., 2012). An antiphase behaviour in the hydrological signal, with wet MCA and dry LIA, has also been recorded in some eastern Mediterranean lakes (Roberts et al., 2011). This Mediterranean see-saw pattern might be related to the higher influence of the NAO in westernmost areas, like the Southern Pyrenees. Thus, the NAO appears to be one of the main climatic mechanisms influencing rainfall variability in the Southern Pyrenees at a centennial timescale during the last millennium. Further research will clarify a more precise timing a spatial variability of the reconstructed climate changes in the context of the IP.

\section{Conclusions}

Paleoclimatic records from the Southern Pyrenees, including lacustrine and marine-littoral sequences, tree rings, and records of glacier fluctuations, evidence a broadly consistent pattern at centennial to multi-decadal timescales for hydrological and thermal fluctuations during the last millennium, likely due to a common climate forcing.

Warmer and arid conditions prevailed during the MCA (up to $1300 \mathrm{AD}$ ) and colder and humid conditions, evidenced by higher lake levels, increased runoff and a change in dominant vegetation during the LIA (1300-1800 AD). Although the LIA is characterized by a complex internal structure, two major phases of environmental change can be identified in all the records within this period: (i) a transitional phase MCALIA, characterized by fluctuating, moist conditions and relatively cold temperatures (ca. 1300 and 1600 AD); and (ii) a second period, characterized by lower temperatures, higher runoff and more positive water balances, coinciding with maximum (recent) glacier advances in the second half of the LIA (ca. 1600-1800 AD)

A synchronous increase in temperature and aridity, coinciding with glacier retreat is found in all the records after $1800 \mathrm{AD}$, coinciding with the end of the LIA. A short-living return towards colder conditions and glacier stabilisation occurred during the late 19th-early 20th century, leading to warmer and more arid conditions afterwards.

Climatic oscillations reconstructed for the last millennium are consistent with other reconstructions from the Western Mediterranean area and glacier fluctuations are also in phase with other Western European (i.e. Alps) and Mediterranean mountains (e.g. Apennines and Balkans). A broadly consistent response to phases of low solar activity has also been found, generally characterized by colder and more humid conditions, unlike in other areas of the IP, and a clear pattern regarding the climatic response on volcanic eruptions 
was not found. Hydrological changes in the Southern Pyrenees correlate with reconstructed NAO variability, which appears to be one of the main climate mechanisms influencing centennial-scale variations in precipitation totals during the last millennium.

Acknowledgements. This research has been funded by the Spanish InterMinistry of Science and Technology (CICYT), through the projects LIMNOCAL (CGL2006-13327-C04-01), GLOBALKARST (REN2003-09130-C02-02), GRACCIECONSOLIDER (CSD2007-00067), DINAMO (CGL2009-64507992) and CRYOMONT (CGL2010-19724). Additional support was provided by the Spanish National Parks Agency through the project HORDA (083/2009). M. Morellón is supported by a Postdoctoral fellowship funded by the Spanish Ministry of Education and Science through FECYT (Spanish Foundation for Science and Technology), A. Pérez-Sanz is supported by a pre-doctoral fellowship funded by the Regional Aragonese Government and A. Moreno acknowledges the "Ramón y Cajal" postdoctoral program for funding. Miguel Sevilla is acknowledged for his help with Fig. 1. We thank Gerardo Benito, William Fletcher, Lourdes López-Merino and anonymous referee for their helpful comments and their criticism, which led to a considerable improvement of the manuscript.

Edited by: F. Domínguez-Castro

\section{References}

Abrantes, F., Lebreiro, S., Rodrigues, T., Gil, I., Bartels-Jonsdottir, H., Oliveira, P., Kissel, C., and Grimalt, J. O.: Shallow-marine sediment cores record climate variability and earthquake activity off Lisbon (Portugal) for the last 2000 years, Quaternary Sci. Rev., 24, 2477-2494, 2005.

Aniol, R. W.: Tree-ring analysis using CATRAS, Dendrochronologia, 1, 45-53, 1983.

Bal, M.-C., Pelachs, A., Perez-Obiol, R., Julia, R., and Cunill, R.: Fire history and human activities during the last $3300 \mathrm{cal}$ yr BP in Spain's Central Pyrenees: The case of the Estany de Burg, Palaeogeogr. Palaeocl., 300, 179-190, 2011.

Bard, E., Raisbeck, G., Yiou, F., and Jouzel, J.: Solar irradiance during the last 1200 years based on cosmogenic nuclides, Tellus B, 52, 985-992, 2000.

Beniston, M.: Climatic Change in Mountain Regions: A Review of Possible Impacts, Climatic Change, 59, 5-31, 2003.

Benito, G., Machado, M. J., and Pérez-González, A.: Climate change and flood sensitivity in Spain, in: Global Continental Changes: The Context of Palaeohydrology, edited by: Branson, J., Brown, A. G., and Gregory, K. J., Special PublicationGeological Society of London, London (UK), 85-98, 1996.

Benito, G., Díez-Herrero, A., and Fernández de Villalta, M.: Magnitude and Frequency of Flooding in the Tagus Basin (Central Spain) over the Last Millennium, Climatic Change, 58, 171-192, 2003.

Bertran, P., Bateman, M. D., Hernandez, M., Mercier, N., Millet, D., Sitzia, L., and Tastet, J.-P.: Inland aeolian deposits of southwest France: facies, stratigraphy and chronology, J. Quaternary Sci., 26, 374-378, 2011.
Blanco-Castro, E., Casado, M., Costa, M., Escribano, R., García Antón, M., Génova, M., Gómez, A., Moreno, J., Morla, C., Regato, P., and Sainz Ollero, H.: Los bosques ibéricos. Una interpretación geobotánica, Planeta, Barcelona (Spain), 572 pp., 1997.

Brázdil, R., Pfister, C., Wanner, H., Storch, H. V., and Luterbacher, J.: Historical climatology in europe - the state of the art, Climatic Change, 70, 363-430, 10.1007/s10584-005-5924-1, 2005.

Brázdil, R., Dobrovolný, P., Luterbacher, J., Moberg, A., Pfister, C., Wheeler, D., and Zorita, E.: European climate of the past 500 years: New challenges for historical climatology, Climatic Change, 101, 7-40, doi:10.1007/s10584-009-9783-z, 2010.

Briffa, K. R.: Annual climate variability in the Holocene: interpreting the message of ancient trees, Quaternary Sci. Rev., 19, 87-105, 2000.

Büntgen, U., Frank, D., Grudd, H., and Esper, J.: Long-term summer temperature variations in the Pyrenees, Clim. Dynam., 31, 615-631, 2008.

Büntgen, U., Franke, J., Frank, D., Wilson, R., GonzálezRouco, F., and Esper, J.: Assessing the spatial signature of European climate reconstructions, Clim. Res., 41, 125-130, 10.3354/cr00848, 2010a.

Büntgen, U., Trouet, V., Frank, D., Leuschner, H. H., Friedrichs, D., Luterbacher, J., and Esper, J.: Tree-ring indicators of German summer drought over the last millennium, Quaternary Sci. Rev., 29, 1005-1016, doi:10.1016/j.quascirev.2010.01.003, 2010b.

Büntgen, U., Tegel, W., Nicolussi, K., McCormick, M., Frank, D., Trouet, V., Kaplan, J. O., Herzig, F., Heussner, K.-U., Wanner, H., Luterbacher, Jr., and Esper, J.: 2500 Years of European Climate Variability and Human Susceptibility, Science, 331, 578582, doi:10.1126/science.1197175, 2011.

Cacho, I., Valero-Garcés, B., and González-Sampériz, P.: Revisión de las reconstrucciones paleoclimáticas en la Península Ibérica desde el último periodo glacial, in: Clima en España: pasado presente y futuro. Informe de evaluación del cambio climático regional, edited by: Pérez, F. F. and Boscolo, R., Red temática Clivar-España, Madrid, Spain, 2010.

Camarero, L., Masqué, P., Devos, W., Ani-Ragolta, I., Catalan, J., Moor, H. C., Pla, S., and Sanchez-Cabeza, J. A.: Historical Variations in Lead Fluxes in the Pyrenees (Northeast Spain) from a Dated Lake Sediment Core, Water Air. Soil Pollut., 105, 439449, 1998.

Camuffo, D., Bertolin, C., Barriendos, M., Dominguez-Castro, F., Cocheo, C., Enzi, S., Sghedoni, M., della Valle, A., Garnier, E., Alcoforado, M. J., Xoplaki, E., Luterbacher, J., Diodato, N., Maugeri, M., Nunes, M., and Rodriguez, R.: 500-year temperature reconstruction in the Mediterranean Basin by means of documentary data and instrumental observations, Climatic Change, 101, 169-199, doi:10.1007/s10584-010-9815-8, 2010.

Catalan, J., Pla, S., García, J., and Camarero, L.: Climate and $\mathrm{CO}_{2}$ saturation in an alpine lake throughout the Holocene, Limnol Oceanogr., 54, 2542-2552, 2009.

Chueca Cía, J., Julián Andrés, A., Saz Sánchez, M. A., Creus Novau, J., and López Moreno, J. I.: Responses to climatic changes since the Little Ice Age on Maladeta Glacier (Central Pyrenees), Geomorphology, 68, 167-182, 2005.

Chueca, J., Peña, J. L., Lampre, F., García Ruiz, J. M., and Martí, C. E.: Los glaciares del Pirineo aragonés: estudio de su evolución y extensión actual, edited by: Departamento de Geografía, U. y. 
O. d. T., Universidad de Zaragoza, Zaragoza (Spain), 1998a.

Chueca, J., Peña, J. L., Lampre, F., and Julián, A.: La Pequeña Edad del Hielo en el Pirineo Central y Meridional. Inferencias paleoambientales a partir de datos geomorfológicos, in: Las huellas glaciares de las montañas españolas, edited by: Gómez Ortiz, A. and Pérez Alberti, A., Universidad de Santiago de Compostela, Santiago de Compostela (Spain), 307-328, 1998 b.

Constante, A., Peña, J. L., Muñoz, A., and Picazo, J.: Climate and anthropogenic factors affecting alluvial fan development during the late Holocene in the central Ebro Valley, northeast Spain, The Holocene, 21, 275-286, doi:10.1177/0959683610378873, 2011.

Cook, E. R. and Kairiukstis, L. A.: Methods of dendrochronology, Kluwer Academic Publishers, London (UK), 394 pp., 1990.

Corella, J. P.: Climate and Human Impact in Northern Spain since Mid-Holocene: the High Resolution Records of Lakes Arreo and Montcortès, Unpublished Phd thesis, Department of Earth Sciences, University of Zaragoza, Zaragoza (Spain), 223 pp., 2011.

Corella, J. P., Amrani, A., Sigró, J., Morellón, M., Rico, E., and Valero-Garcés, B.: Recent evolution of Lake Arreo, northern Spain: influences of land use change and climate, J. Paleolimnol., 46, 469-485, 2011a.

Corella, J. P., Valero-Garcés, B., Moreno, A., Morellón, M., Rull, V., Giralt, S., Rico, M. T., and Pérez-Sanz, A.: Climate and human impact on a meromictic lake during the last 6000 years (Montcortès Lake, Central Pyrenees, Spain) J. Paleolimnol., 46, 351-367, 2011b.

Cuadrat, J. M., Saz Sánchez, M. A., and Vicente Serrano, S. M.: Atlas climático de Aragón, Departamento de Medio Ambiente, Gobierno de Aragón, 2008.

Cullen, H. M. and deMenocal, P. B.: North Atlantic influence on Tigris-Euphrates streamflow, Int. J. Climatol., 20, 853-863, 2000.

D'Andrea, W. J., Huang, Y., Fritz, S. C., and Anderson, N. J.: Abrupt Holocene climate change as an important factor for human migration in West Greenland, Proc. Natl. Acad. Sci., 108, 9765-9769, doi:10.1073/pnas.1101708108, 2011.

Del Barrio, G., Creus, J., and Puigdefabregas, J.: Thermal Seasonality of the High Mountain Belts of the Pyrenees, Mt. Res. Dev., 10, 227-233, 1990.

Denton, G. H. and Broecker, W. S.: Wobbly ocean conveyor circulation during the Holocene?, Quaternary Sci. Revi., 27, 19391950, 2008.

Détriché, S., Bréhéret, J. G., Soulié-Märsche, I., Karrat, L., and Macaire, J. J.: Late Holocene water level fluctuations of Lake Afourgagh (Middle-Atlas Mountains, Morocco) inferred from charophyte remains, Palaeogeogr. Palaeocl., 283, 134-147, 2009.

Dezileau, L., Sabatier, P., Blanchemanche, P., Joly, B., Swingedouw, D., Cassou, C., Castaings, J., Martinez, P., and Von Grafenstein, U.: Intense storm activity during the Little Ice Age on the French Mediterranean coast, Palaeogeogr. Palaeocl., 299, 289-297, 2011.

Ejarque, A., Miras, Y., Riera, S., Palet, J. M., and Orengo, H. A.: Testing micro-regional variability in the Holocene shaping of high mountain cultural landscapes: a palaeoenvironmental casestudy in the eastern Pyrenees, J. Archaeol. Sci., 37, 1468-1479, doi:10.1016/j.jas.2010.01.007, 2010.

Esper, J., Frank, D., Büntgen, U., Verstege, A., Luterbacher, J., and Xoplaki, E.: Long-term drought severity variations in Morocco,
Geophys. Res. Lett., 34, L17702, doi:10.1029/2007GL030844, 2007.

Fagan, B. M.: The Little Ice Age: how climate made history, 13001850, Basic Books, New York (USA), 2000.

Fletcher, W. J. and Zielhofer, C.: Fragility of Western Mediterranean landscapes during Holocene Rapid Climate Changes, CATENA, doi:10.1016/j.catena.2011.05.001, in press, 2012.

Font-Tullot, I.: Cambios climáticos en la Península Ibérica durante el último milenio, con especial referencia a la "Pequeña Edad Glacial”, in: Quaternary Climate in Western Mediterranean, Proceedings of the Symposium on Climatic Fluctuations during the Quaternary in the Western Mediterranean Regions, edited by: López-Vera, F., Universidad Autónoma de Madrid, Madrid, Spain, 1986.

Frank, D. C., Esper, J., Raible, C. C., Buntgen, U., Trouet, V., Stocker, B., and Joos, F.: Ensemble reconstruction constraints on the global carbon cycle sensitivity to climate, Nature, 463, 527-530, 2010.

Fritts, H. C.: Modeling tree-ring and environmental relationships or dendrochronological analysis, in: Forest growth: Process modeling of responses to environmental stress, edited by: Dixon, R. K., Meldahl, R. S., Ruark, G. A., and Warren, W. G., Timber Press, Oregon (USA), 368-382, 1990.

Fritts, H. C. and Shashkin, A. V.: Modelling tree-ring structure as related to temperature, precipitation and day length, in: Tree Rings as Indicators of Ecosystem Health, edited by: Lewis, T. E., CRC Press, Boca Raton, FL, 17-57, 1995.

Galop, D., Houet, T., Mazier, F., Leroux, G., and Rius, D.: Grazing activities and biodiversity in the Pyrenees: new insight on high altitude ecosystems in the framework of a Human-Environment Observatory, PAGES News, 19, 53-55, 2011.

Gao, C., Robock, A., and Ammann, C.: Volcanic forcing of climate over the past 1500 years: An improved ice core-based index for climate models, J. Geophys. Res., 113, D23111, doi:10.1029/2008JD010239, 2008.

García-Ruiz, J. M., López-Moreno, J. I., Vicente-Serrano, S. M., Lasanta-Martínez, T., and Beguería, S.: Mediterranean water resources in a global change scenario, Earth-Sci. Rev., 105, 121139, 2011.

García, M. B. and Gómez, D.: Flora del pirineo aragonés. Patrones espaciales de biodiversidad y su relevancia para la conservación, Pirineos, 162, 71-88, 2008.

Giraudi, C.: Middle to Late Holocene glacial variations, periglacial processes and alluvial sedimentation on the higher Apennine massifs (Italy), Quaternary Res., 64, 176-184, 2005.

Giraudi, C., Magny, M., Zanchetta, G., and Drysdale, R. N.: The Holocene climatic evolution of Mediterranean Italy: A review of the continental geological data, The Holocene, 21, 105-115, doi:10.1177/0959683610377529, 2011.

Gómez-Navarro, J. J., Montávez, J. P., Jerez, S., Jiménez-Guerrero, P., Lorente-Plazas, R., González-Rouco, J. F., and Zorita, E.: A regional climate simulation over the Iberian Peninsula for the last millennium, Clim. Past, 7, 451-472, doi:10.5194/cp-7-4512011, 2011.

Gómez Ortiz, A., Schulte, L., Salvador, F., Sánchez, S., and Simón, M.: Geomorphological Map of Sierra Nevada. Glacial and Periglacial Geomorphology, Consejería de Medio Ambiente, Junta de Andalucía, Granada, Spain, 2002.

Gómez Ortiz, A., Palacios, D., Schulte, L., Salvador-Franch, F., 
and Plana-CastellvÍ, J. A.: Evidences from historical documents of landscape evolution after Little Ice Age of a Mediterranean high mountain area, Sierra Nevada, Spain (eighteenth to twentieth centuries), Geografiska Annaler: Series A, Physical Geography, 91, 279-289, doi:10.1111/j.1468-0459.2009.00370.x, 2009.

González-Trueba, J. J.: Topoclimatical factors and very small glaciers in Atlantic Mountain of SW Europe: The Little Ice Age glacier advance in Picos de Europa (NW Spain), Zeitschrift für Gletscherkunde und Glazialgeologie, 39, 115-125, 2006.

González-Trueba, J. J.: La Pequeña Edad del Hielo en los Picos de Europa, Universidad de Cantabria, Santander, Spain, 2007.

González Trueba, J. J., Moreno, R. M., Martinez de Pison, E., and Serrano, E.: "Little Ice Age" glaciation and current glaciers in the Iberian Peninsula, The Holocene, 18, 551-568, doi:10.1177/0959683608089209, 2008.

Goodkin, N. F., Hughen, K. A., Doney, S. C., and Curry, W. B.: Increased multidecadal variability of the North Atlantic Oscillation since 1781, Nature Geosci, 1, 844-848, 2008.

Graham, N., Ammann, C., Fleitmann, D., Cobb, K., and Luterbacher, J.: Support for global climate reorganization during the "Medieval Climate Anomaly", Clim. Dynam., 37, 1217-1245, doi:10.1007/s00382-010-0914-z, 2011.

Grove, J. M. and Gellatly, A. F.: Little Ice Age fluctuations in the Pyrenees, Zeitschrift für Gletcherkunde und Glacialgeologie, 31, 199-206, 1995.

Holmes, R.: Dendrochronology program library. Guide for computer program COFECHA, Laboratory of Tree-Ring Research, Arizona, USA, 1986.

Hughes, P. D.: Little Ice Age glaciers in the Balkans: low altitude glaciation enabled by cooler temperatures and local topoclimatic controls, Earth Surf. Proc. Land., 35, 229-241, 2010.

Jansen, E., Overpeck, J., Briffa, K. R., Duplessy, J.-C., Joos, F., Masson-Delmotte, V., Olago, D., Otto-Bliesner, B., Peltier, W. R., Rahmstorf, S., Ramesh, R., Raynaud, D., Rind, D., Solomina, O., Villalba, R., and Zhang, D.: Palaeoclimate, in: Climate Change 2007: The Physical Science Basis., Intergovernmental Panel on Climate Change, Cambridge, United Kingdom and New York, NY, USA, Contribution of Working Group I to the Fourth Assessment Report of the Intergovernmental Panel on Climate Change, edited by: Solomon, S., Qin, D., Manning, M., Chen, Z., Marquis, M., Averyt K. B., Tignor, M., and Miller, H. L., Cambridge University Press, , 2007.

Jones, P. D., Briffa, K. R., Barnett, T. P., and Tett, S. F. B.: Highresolution palaeoclimatic records for the last millennium: interpretation, integration and comparison with General Circulation Model control-run temperatures, The Holocene, 8, 455-471, doi:10.1191/095968398667194956, 1998.

Jones, P. D., Briffa, K. R., Osborn, T. J., Lough, J. M., van Ommen, T. D., Vinther, B. M., Luterbacher, J., Wahl, E. R., Zwiers, F. W., Mann, M. E., Schmidt, G. A., Ammann, C. M., Buckley, B. M., Cobb, K. M., Esper, J., Goosse, H., Graham, N., Jansen, E., Kiefer, T., Kull, C., Kuttel, M., Mosley-Thompson, E., Overpeck, J. T., Riedwyl, N., Schulz, M., Tudhope, A. W., Villalba, R., Wanner, H., Wolff, E., and Xoplaki, E.: Highresolution palaeoclimatology of the last millennium: a review of current status and future prospects, The Holocene, 19, 3-49, doi:10.1177/0959683608098952, 2009.

Julià, R., Burjachs, F., Dasí, M. J., Mezquita, F., Miracle, M. R., Roca, J. R., Seret, G., and Vicente, E.: Meromixis origin and recent trophic evolution in the Spanish mountain lake La Cruz, Aquatic Sciences - Research Across Boundaries, 60, 279-299, 1998.

Kanner, L. C., Burns, S. J., Cheng, H., and Edwards, R. L.: High-Latitude Forcing of the South American Summer Monsoon During the Last Glacial, Science, 335, 570-573, doi:10.1126/science.1213397, 2012.

Last, W. M. and Smol, J. P.: Tracking Environmental Change using Lake Sediments, Developments in Paleoenvironmental Research Series, Kluwer Academic Publishers, Norwell, MA, USA, 2001.

Lebreiro, S. M., Francés, G., Abrantes, F. F. G., Diz, P., BartelsJónsdóttir, H. B., Stroynowski, Z. N., Gil, I. M., Pena, L. D., Rodrigues, T., Jones, P. D., Nombela, M. A., Alejo, I., Briffa, K. R., Harris, I., and Grimalt, J. O.: Climate change and coastal hydrographic response along the Atlantic Iberian margin (Tagus Prodelta and Muros Ría) during the last two millennia, The Holocene, 16, 1003-1015, doi:10.1177/0959683606hl990rp, 2006.

Liu, J., Wang, B., Ding, Q., Kuang, X., Soon, W., and Zorita, E.: Centennial Variations of the Global Monsoon Precipitation in the Last Millennium: Results from ECHO-G Model, J. Climate, 22, 2356-2371, doi:10.1175/2008jcli2353.1, 2009.

López-Merino, L., Moreno, A., Leira, M., Sigró, J., GonzálezSampériz, P., Valero-Garcés, B. L., López-Sáez, J. A., Brunet, M., and Aguilar, E.: Two hundred years of environmental change in Picos de Europa National Park inferred from sediments of LagoEnol, northern Iberia, J. Paleolimnol., 46, 453467, doi:10.1007/s10933-011-9546-5, 2011.

López-Moreno, J. I. and García-Ruiz, J. M.: Influence of snow accumulation and snowmelt on streamflow in the central Spanish Pyrenees, Hydrolog. Sci. J., 49, 787-802, 2004.

López-Moreno, J. I., Goyette, S., and Beniston, M.: Climate change prediction over complex areas: spatial variability of uncertainties and predictions over the Pyrenees from a set of regional climate models, Int. J. Climatol., 28, 1535-1550, 2008.

López-Sáez, J. A., López-Merino, L., Mateo, M. Á., Serrano, Ó., Pérez-Díaz, S., and Serrano, L.: Palaeoecological potential of the marine organic deposits of Posidonia oceanica: A case study in the NE Iberian Peninsula, Palaeogeogr. Palaeocl., 271, 215-224, 2009.

Luterbacher, J., Xoplaki, E., Casty, C., Wanner, H., Pauling, A., Küttel, M., Rutishauser, T., Brönnimann, S., Fischer, E., Fleitmann, D., González-Rouco, F. J., García-Herrera, R., Barriendos, M., Rodrigo, F., Gonzalez-Hidalgo, J. C., Saz, M. A., Gimeno, L., Ribera, P., Brunet, M., Paeth, H., Rimbu, N., Felis, T., Jacobeit, J., Dünkeloh, A., Zorita, E., Guiot, J., Türkes, M., Alcoforado, M. J., Trigo, R., Wheeler, D., Tett, S., Mann, M. E., Touchan, R., Shindell, D. T., Silenzi, S., Montagna, P., Camuffo, D., Mariotti, A., Nanni, T., Brunetti, M., Maugeri, M., De Zerefos, C., Zolt, S., and Lionello, P.: Mediterraneanclimatevariability over the last centuries: areview, in: The Mediterraneanclimate: An overview of the main characteristics and issues, edited by: Lionello, P., Malanotte-Rizzoli, P., and Boscolo, R., Elsevier, Amsterdam, The Netherlands, 27-148, 2005.

Magny, M., Gauthier, E., Vanniere, B., and Peyron, O.: Palaeohydrological changes and human-impact history over the last millennium recorded at Lake Joux in the Jura Mountains, Switzerland, The Holocene, 18, 255-265, doi:10.1177/0959683607086763, 2008. 
Magny, M., Arnaud, F., Holzhauser, H., Chapron, E., Debret, M., Desmet, M., Leroux, A., Millet, L., Revel, M., and Vannière, B.: Solar and proxy-sensitivity imprints on paleohydrological records for the last millennium in west-central Europe, Quaternary Res., 73, 173-179, 2010.

Magny, M., Bossuet, G., Ruffaldi, P., Leroux, A., and Mouthon, J.: Orbital imprint on Holocene palaeohydrological variations in west-central Europe as reflected by lake-level changes at Cerin (Jura Mountains, eastern France), J. Quaternary Sci., 26, 171177, 2011a.

Magny, M., Peyron, O., Gauthier, E., Vannière, B., Millet, L., and Vermot-Desroches, B.: Quantitative estimates of temperature and precipitation changes over the last millennium from pollen and lake-level data at Lake Joux, Swiss Jura Mountains, Quaternary Res., 75, 45-54, 2011 b.

Mann, M. E. and Bradley, R. S.: Northern Hemisphere temperatures during the past millennium: inferences, uncertainties, and limitations, Geophys. Res. Lett., 26, 759-762, 1999.

Mann, M. E. and Jones, P. D.: Global surface temperatures over the past two millennia, Geophys. Res. Lett., 30, 1820, doi:10.1029/2003GL017814, 2003.

Mann, M. E., Zhang, Z., Hughes, M. K., Bradley, R. S., Miller, S. K., Rutherford, S., and Ni, F.: Proxy-based reconstructions of hemispheric and global surface temperature variations over the past two millennia, Proce. Natl. Acad. Sci., 105, 13252-13257, doi:10.1073/pnas.0805721105, 2008.

Martín-Puertas, C., Valero-Garcés, B. L., Mata, M. P., GonzálezSampériz, P., Bao, R., Moreno, A., and Stefanova, V.: Arid and humid phases in southern Spain during the last 4000 years: the Zonar Lake record, Cordoba, The Holocene, 18, 907-921, doi:10.1177/0959683608093533, 2008.

Martín-Puertas, C., Jiménez-Espejo, F., Martínez-Ruiz, F., NietoMoreno, V., Rodrigo, M., Mata, M. P., and Valero-Garcés, B. L.: Late Holocene climate variability in the southwestern Mediterranean region: an integrated marine and terrestrial geochemical approach, Clim. Past, 6, 807-816, doi:10.5194/cp-6-807-2010, 2010.

Martín-Puertas, C., Dorado-Liñán, I., Brauer, A., Zorita, E., ValeroGarcés, B. L., and Gutierrez, E.: Hydrological evidence for a North Atlantic oscillation during the Little Ice Age outside its range observed since 1850, Clim. Past Discuss., 7, 4149-4171, doi:10.5194/cpd-7-4149-2011, 2011.

Miras, Y., Ejarque, A., Riera, S., Palet, J. M., Orengo, H., and Euba, I.: Dynamique holocène de la végétation et occupation des Pyrénées andorranes depuis le Néolithique ancien, d'après l'analyse pollinique de la tourbière de Bosc dels Estanyons (2180 m, Vall del Madriu, Andorre), Comptes Rendus Palevol, 6, 291-300, 2007.

Montserrat-Martí, J.: Evolución glaciar y postglaciar del clima y la vegetación en la vertiente sur del Pirineo: estudio palinológico., Monografías del Instituto Pirenaico de EcologíaCSIC, Zaragoza, 147 pp., 1992.

Morellón, M., Valero-Garcés, B., González-Sampériz, P., VegasVilarrúbia, T., Rubio, E., Rieradevall, M., Delgado-Huertas, A., Mata, P., Romero, Ó., Engstrom, D. R., López-Vicente, M., Navas, A., and Soto, J.: Climate changes and human activities recorded in the sediments of Lake Estanya (NE Spain) during the Medieval Warm Period and Little Ice Age, J. Paleolimnol., 46, 423-452, 2011.
Moreno, A., Valero-Garcés, B. L., González-Sampériz, P., and Rico, M.: Flood response to rainfall variability during the last 2000 years inferred from the Taravilla Lake record (Central Iberian Range, Spain), J. Paleolimnol., 40, 943-961, 2008.

Moreno, A., Morellón, M., Martín-Puertas, C., Frigola, J., Canals, M., Cacho, I., Corella, J. P., Pérez, A., Belmonte, Á., VegasVilarrúbia, T., González-Sampériz, P., and Valero-Garcés, B. L.: Was there a common hydrological pattern in the Iberian Peninsula region during the Medieval Climate Anomaly?, PAGES News, 19, 16-18, 2011.

Moreno, A., Pérez, A., Frigola, J., Nieto-Moreno, V., RodrigoGámiz, M., González-Sampériz, P., Morellón, M., MartínPuertas, C., Corella, J. P., Belmonte, Á., Sancho, C., Cacho, I., Herrera, G., Canals, M., Jiménez-Espejo, F., Martínez-Ruiz, F., Vegas, T., and Valero-Garcés, B. L.: The Medieval Climate Anomaly in the Iberian Peninsula reconstructed from marine and lake records, Quaternary Sci. Rev., in press, 2012.

Nieto-Moreno, V., Martínez-Ruiz, F., Giralt, S., Jiménez-Espejo, F., Gallego-Torres, D., Rodrigo-Gámiz, M., García-Orellana, J., Ortega-Huertas, M., and de Lange, G. J.: Tracking climate variability in the western Mediterranean during the Late Holocene: a multiproxy approach, Clim. Past, 7, 1395-1414, doi:10.5194/cp7-1395-2011, 2011.

North, G. R., Biondi, F., Bloomfield, P., Christy, J. R., Cuffey, K. M., Dickinson, R. E., Druffel, E. R. M., Nychka, D., OttoBliesner, B., Roberts, N., Turekian, K. K., and Wallace, J. M.: Surface Temperature Reconstructions for the Last 2,000 Years, edited by: Years, C. o. S. T. R. f. t. L., The National Academies Press, Washington D.C., USA, 2006.

Paasche, Ø. and Bakke, J.: Defining the Little Ice Age, Clim. Past Discuss., 6, 2159-2175, doi:10.5194/cpd-6-2159-2010, 2010.

Patterson, W. P., Dietrich, K. A., Holmden, C., and Andrews, J. T.: Two millennia of North Atlantic seasonality and implications for Norse colonies, Proc. Natl. Acad. Sci., 107, 5306-5310, doi:10.1073/pnas.0902522107, 2010.

Pauling, A., Luterbacher, J., Casty, C., and Wanner, H.: Five hundred years of gridded high-resolution precipitation reconstructions over Europe and the connection to large-scale circulation, Clim. Dynam., 26, 387-405, 2006.

Peinado Lorca, M. and Rivas-Martínez, S.: La vegetación de España, Colección Aula Abierta, 544 pp., 1987.

Pérez-Sanz, A.: Reconstrucción paleoambiental del Ibón de la Basa de la Mora (Pirineo Central): Primeros resultados del análisis palinológico. Trabajo de fin de máster, Master Ciencias de la Tierra, Universidad de Zaragoza, Zaragoza, Spain, 2009.

Pérez Sanz, A., González-Sampériz, P., Valero-Garcés, B., Moreno, A., Morellón, M., Sancho, C., Belmonte, A., Gil-Romera, G., Sevilla, M., and Navas, A.: Clima y actividades humanas en la dinámica de la vegetación durante los últimos 2000 años en el Pirineo Central: el registro palinológico de la Basa de la Mora (Macizo de Cotiella), Zubia, 23, 1-7-38, 2011.

Pla, S. and Catalán, J.: Chrysophyte cysts from lake sediments reveal the submillennial winter/spring climate variability in the northwestern Mediterranean region throughout the Holocene, Clim. Dynam., 24, 263-278, 2005.

Pla-Rabes, S. and Catalan, J.: Deciphering chrysophyte responses to climate seasonality, J. Paleolimnol., 46, 139-150, 2011.

Proctor, C., Baker, A., and Barnes, W.: A three thousand year record of North Atlantic climate, Clim. Dynam., 19, 449-454, 2002. 
Puente, J. M.: Cuando el río se helaba. Las heladas históricas del Ebro a su paso por Tortosa., Revista del Aficionado a la Meteorología, 1, 2007.

Roberts, N., Moreno, A., Valero-Garcés, B. L., Corella, J. P., Jones, M., Allcock, S., Woodbridge, J., Morellón, M., Luterbacher, J., Xoplaki, E., and Türkeş, M.: Palaeolimnological evidence for an east-west climate see-saw in the Mediterranean since AD 900, Global Planet. Change, 84-85, 23-24, 10.1016/j.gloplacha.2011.11.002, 2012.

Rius, D., Vannière, B., and Galop, D.: Holocene history of fire, vegetation and land use from the central Pyrenees (France), Quaternary Res., 77, 54-64, 2012.

Rull, V., González-Sampériz, P., Corella, J., Morellón, M., and Giralt, S.: Vegetation changes in the southern Pyrenean flank during the last millennium in relation to climate and human activities: the Montcortès lacustrine record, J. Paleolimnol., 46, 387-404, 2011.

Sancho, C., Peña, J. L., Muñoz, A., Benito, G., McDonald, E., Rhodes, E. J., and Longares, L. A.: Holocene alluvial morphopedosedimentary record and environmental changes in the BardenasReales Natural Park (NE Spain), CATENA, 73, 225238, doi:10.1016/j.catena.2007.09.011, 2008.

Saz Sánchez, M. A.: Temperaturas y precipitaciones en la mitad norte de España desde el siglo XV. Estudio Dendroclimático, Serie Investigación, Publicaciones del Consejo de la Naturaleza de Aragón, Zaragoza, Spain, 2003.

Scussolini, P., Vegas-Vilarrúbia, T., Rull, V., Corella, J., ValeroGarcés, B., and Gomà, J.: Middle and late Holocene climate change and human impact inferred from diatoms, algae and aquatic macrophyte pollen in sediments from Lake Montcortès, (NE Iberian Peninsula), J. Paleolimnol., 46, 369-385, 2011.

Schaefer, J. M., Denton, G. H., Kaplan, M., Putnam, A., Finkel, R. C., Barrell, D. J. A., Andersen, B. G., Schwartz, R., Mackintosh, A., Chinn, T., and Schluchter, C.: HighFrequency Holocene Glacier Fluctuations in New Zealand Differ from the Northern Signature, Science, 324, 622-625, doi:10.1126/science.1169312, 2009.

Serrano, E. and Martínez de Pisón, E.: Geomorfología y evolución glaciar en el Pirineo aragonés oriental, in: El glaciarismo surpirenaico. Nuevas aportaciones, edited by: Martí, C. E. and García, J. M., Geoforma ediciones, 33-64, 1994.

Serrano, E., González-Trueba, J. J., Sanjosé, J. J., and Del Río, L. M.: Ice patch origin, evolution and dynamics in a temperate high mountain environment: The Jou Negro, Picos de Europa (NW Spain), Geografiska Annaler: Series A, Phys. Geogr., 93, 57-70, doi:10.1111/j.1468-0459.2011.00006.x, 2011.
Shindell, D. T., Miller, R. L., Schmidt, G. A., and Pandolfo, L.: Simulation of recent northern winter climate trends by greenhouse-gas forcing, Nature, 399, 452-455, 1999.

Solomon, S., Qin, D., Manning, M., Marquis, M., Averyt, K., Tignor, M. M. B., Miller, H., and Chen, Z.: Climate Change 2007: The Physical Science Basis. Contribution of Working Group I to the Fourth Assessment Report of the Intergovernmental Panel on Climate Change, Cambridge University Press, Cambridge, 2007.

Sousa, A. and García-Murillo, P.: Changes in the Wetlands of Andalusia (Doñana Natural Park, SW Spain) at the End of the Little Ice Age, Climatic Change, 58, 193-217, 2003.

Steinhilber, F., Beer, J., and Fröhlich, C.: Total solar irradiance during the Holocene, Geophys. Res. Lett., 36, L19704, doi:10.1029/2009GL040142, 2009.

Touchan, R., Anchukaitis, K., Meko, D., Sabir, M., Attalah, S., and Aloui, A.: Spatiotemporal drought variability in northwestern Africa over the last nine centuries, Clim. Dynam., 37, 237-252, doi:10.1007/s00382-010-0804-4, 2011.

Trigo, R. M., Pozo-Vázquez, D., Osborn, T. J., Castro-Díez, Y., Gámiz-Fortis, S., and Esteban-Parra, M. J.: North Atlantic oscillation influence on precipitation, river flow and water resources in the Iberian Peninsula, Int. J. Climatol., 24, 925-944, doi:10.1002/joc.1048, 2004.

Trouet, V. R., Esper, J., Graham, N. E., Baker, A., Scourse, J. D., and Frank, D. C.: Persistent Positive North Atlantic Oscillation Mode Dominated the Medieval Climate Anomaly, Science, 324, 78-80, doi:10.1126/science.1166349, 2009.

Valero-Garcés, B. and Moreno, A.: Iberian lacustrine records: responses to past and recent global changes in the Mediterranean region, J. Paleolimnol., 46, 319-325, 2011.

Van Geel, B.: A palaeoecological study of holocene peat bog sections in Germany and The Netherlands, based on the analysis of pollen, spores and macro- and microscopic remains of fungi, algae, cormophytes and animals, Rev. Palaeobot. Palyno., 25, 1120, 1978.

Vaquero, J. M., Gallego, M. C., and García, J. A.: A 250-year cycle in naked-eye observations of sunspots, Geophys. Res. Lett., 29, 20, doi:10.1029/2002GL014782, 2002.

Vicente-Serrano, S. and Cuadrat, J.: North Atlantic oscillation control of droughts in north-east Spain: evaluation since 1600 a.d., Climatic Change, 85, 357-379, 2007. 